TIMOTHY F. BRESNAHAN

Stanford University

PETER C. REISS

NBER and Stanford University

\title{
Do Entry Conditions Vary across Markets?
}

THE NUMBER OF FIRMS in a market is a primary determinant of market concentration and performance. In the long run the number of firms is affected by the ease with which they can enter and exit. Many recent theoretical models of entry have emphasized that strategic behavior by incumbents may have an important bearing on the number of firms that enter the market. For instance, these models illustrate how the extent of postentry competition and opportunities for erecting strategic entry barriers might affect the likelihood that another firm will enter a market. ${ }^{1}$ In contrast to these strategic models, other models of the long-run number of firms emphasize that technological factors, such as economies of scale, determine entry. These theories minimize the importance of strategic behavior in the long run and instead emphasize that highly concentrated industries are simply ones for which few firms will fit given the degree of returns to scale.

Peter C. Reiss's work was performed in part while he was an Olin fellow at the National Bureau of Economic Research, Cambridge, Massachusetts. We thank Robert Hall, George Stigler, and Robert Willig for comments.

1. See John Roberts, "Battles for Market Share: Incomplete Information, Aggressive Strategic Pricing and Competitive Dynamics," in Truman Bewley, ed., Advances in Economic Theory (Cambridge University Press, 1987); and Richard Gilbert, "Mobility Barriers and the Value of Incumbency," in Richard Schmalensee and Robert Willig, eds., Handbook of Industrial Organization (Amsterdam: North-Holland, forthcoming), for recent reviews of theoretical models of entry. 
Despite the contrasting implications, relatively little empirical work has attempted to distinguish between the two views. ${ }^{2}$ This paper develops a framework for assessing the relative importance of the two views. Specifically, we formulate an empirical model in which both increasing returns and strategic forces affect the number of active firms. Our empirical section uses this framework to predict when a market will have zero, one, or two or more firms. We draw inferences about the presence of scale economies from the size of the market necessary to support one firm. Inferences about the importance of strategic behavior are drawn by observing at what market sizes a second firm enters. The data we use to estimate our model consist of observations on the number of firms in small, isolated retail and professional markets in the United States. This sample offers a new opportunity to study entry in an imperfectly competitive context. In contrast to most entry studies that use aggregate cross-section data on different manufacturing industries (for example, autos and frozen french fries), we have data on firms that are technologically similar. With these data we can reliably determine market boundaries and can control for demand and cost conditions likely to affect entry.

Our distinction between technological and strategic determinants of entry relies on a model of how the number of firms in a market should vary with the size of the market. Our inference procedure is roughly as

2. One group tries to make this distinction by regressing profits measures on proxies for strategic entry barriers; see Richard Schmalensee, "Inter-Industry Empirical Analysis," in Schmalensee and Willig, Handbook of Industrial Organization. Another, smaller group models entry rates or the number of active firms as functions of such entry barrier proxies as the ratio of advertising expenditures to sales, research and development expenditures to sales, and capital to output. See Paul Geroski, "The Empirical Analysis of Entry: A Survey," working paper 8318 (University of Southampton, 1983), for a summary. The use of these proxy variables is highly suspect; they could just as easily measure economies of scale. More recent work on entry that has emphasized technological factors has either assumed markets are perfectly competitive or is silent on competitive or strategic issues. See, for example, Dennis W. Carlton, "The Location and Employment Choices of New Firms: An Econometric Model with Discrete and Continuous Endogenous Variables,"'Review of Economics and Statistics, vol. 65 (August 1983), pp. 440-49; John C. Hause and Gunnar du Rietz, "Entry, Industry Growth, and the Microdynamics of Industry Supply," Journal of Political Economy, vol. 92 (August 1984), pp. 733-57; V. K. Chetty and J. J. Heckman, "A Dynamic Model of Aggregate Output Supply, Factor Demand and Entry and Exit for a Competitive Industry with Heterogeneous Plants," Journal of Econometrics, vol. 33 (October-November 1986), pp. 237-62; and Timothy Dunne, Mark J. Roberts, and Larry Samuelson, "Firm Entry and Exit in U.S. Manufacturing Industries” (Pennsylvania State University, 1987). 
follows. Assume that the size of the market is simply its population, that is, that all markets are identical, except that they have different numbers of identical demanders. Let $S_{M}$ represent the population level below which a market will have no firms and above which the market will have at least one firm. This market size defines the level of demand where variable profits just cover a firm's fixed costs; in other words, it is the entry threshold for monopolies. Similarly, there is a duopoly entry threshold, $S_{D}$, which is the size of the market at which duopoly variable profit just covers a second firm's fixed costs. Our inferences about strategic entry are based on the ratios of these entry thresholds. We term this quantity the entry threshold ratio, $S_{D} / S_{M} \cdot{ }^{3}$ Under fairly mild economic assumptions about the factors that affect entry, this ratio indicates how important strategic factors are. The monopoly entry threshold holds constant the degree of returns to scale from technology. The duopoly threshold thus says something about how early the second firm enters relative to the technology used by the monopolist. In other words, the entry threshold ratio simply reports the degree to which there are few duopolies, taking into account the tendency to have few firms because of scale economies.

This inference obviously requires a more detailed economic justification, which is provided later. Of course, real data are somewhat less cooperative than this introduction suggests. Our actual procedures for measuring the size of the market are therefore somewhat more complex. Subsequent parts of this paper describe how we matched the constructs of entry thresholds to the data and the procedures we used to define markets and to determine the size of the market. Our primary finding is that industries vary dramatically in their entry threshold ratios. We go on to suggest why this finding might be a consequence of sunk costs. We rule out flawed geographic market definition and governmental restrictions on entry as explanations.

\section{Inferences from the Entry Equations}

The intuition for our interpretations of the relationship between market size and the number of firms can readily be given using figure 1 , which plots profit functions, $\Pi$, of a firm as a function of the size of a 
Figure 1. Profits as a Function of Market Size When Duopoly Is Threatened

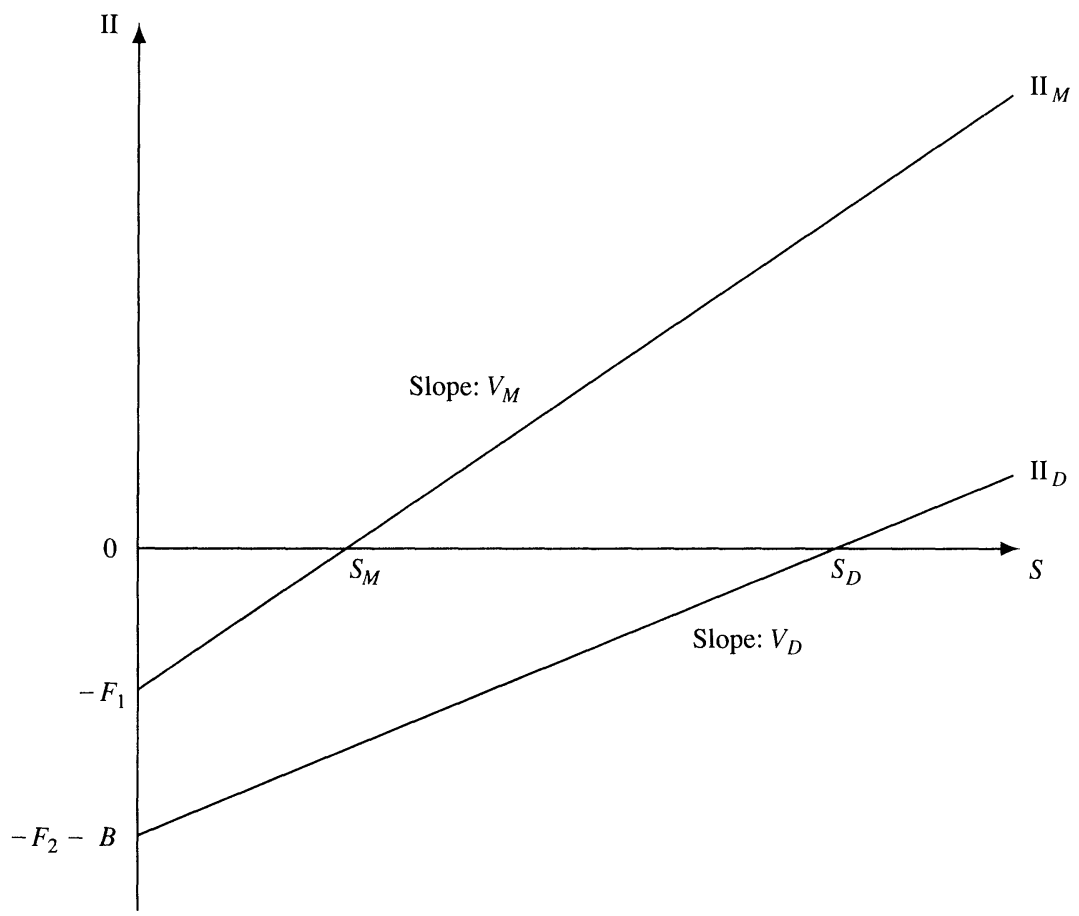

market, $S$. Line $\Pi_{M}$ is the profit function of a monopolist. Line $\Pi_{D}$ is the profit function of the second firm into the market. Markets with insufficient demand to support even one firm occur when $\Pi_{M}<0$. As market size, $S$, increases, there is eventually enough demand to cover long-run fixed costs, and a firm enters at $S_{M}$. In larger markets, $\Pi_{D}>0$, a second firm is profitable. Call the size of the market that just supports a duopoly $S_{D}$. Our empirical plan will be to estimate $S_{D}$ and $S_{M}$, as well as the slopes of lines $\Pi_{M}$ and $\Pi_{D}$.

\section{ECONOMIC QUANTITIES}

The intercepts in figure 1 measure firms' fixed costs. Intercept $F_{1}$ is the fixed costs of the first firm in a market; intercept $F_{2}$ is the second firm's fixed costs. Figure 1 assumes that the first firm in a market is more 
efficient than the second; in particular, it allows for the possibility that entry barriers raise the fixed costs of the second firm by $B .^{4}$

The interpretation of the slopes in figure 1 is more involved. The slopes are the derivative of profit with respect to the size of the market. The figure assumes that the slopes of these profit functions are constants with respect to $S$. In general they need not be, but we later describe plausible economic conditions under which they are likely to be.

The price and quantity strategies of the monopolist and the second firm into the market determine the shape of the reduced-form profit functions in figure 1. These strategies are themselves functions of demand and cost parameters. Let $c_{1}$ denote the marginal costs of the first firm, and $c_{2}$ the marginal costs of the second (we assume that marginal costs are constant). This implies firms' costs are $c_{i}(W) Q+F_{i}(W)$, where $Q$ is unit sales and $W$ represents exogenous variables that affect costs. Firms' costs can differ either because of differences in fixed costs or differences in variable costs. For example, if $c_{2}>c_{1}$, then the second firm is less efficient. Alternatively, entry barriers might imply that the second firm's marginal costs are greater by $b$. The distinction between $b>0$ and $c_{2}>$ $c_{1}$ is that $b$ is the advantage of incumbency per se, while $c_{2}-c_{1}$ is the relative productive efficiency of the first firm into the market. A similar analogy applies for differences between $B$ and $F_{2}-F_{1}$.

We assume that the factors affecting a firm's demand can be divided into determinants of the size of the market, $Y$, and those that affect per capita demand, $Z$. Changes in the size of the market are assumed to rotate the demand curve horizontally. This implies that total demand can be written as $Q=q(Z, P) \times S(Y)$. Here $S(Y)$ is the size of the market and $q(Z, P)$ is per capita demand. In this formulation $S(Y)$ is simply the generalization of market population. We allow it to depend on more than current population in the market. For example, it could include population growth rates or population leakages, ${ }^{5}$ and factors such as distance to the next town, the number of people who commute away from town to work, and so on. In general, any exogenous factor that shifts local

4. We follow the convention of George J. Stigler, The Organization of Industry (Homewood, Ill.: Irwin, 1968), pp. 67-70, in treating all entry barriers as if they shifted entrants' costs. This should be interpreted as including cases in which they worsen the market for the entrant's product.

5. This concept avoids some of the problems that earlier empirical studies have had when they have taken the growth rate of industry sales to be exogenous. 
demand can be included. Per capita demand depends on factors such as per capita income, demographic characteristics, $Z$, and prices, $P$. In this formulation, a doubling of $S$ will lead to a doubling of unit sales at the same prices. For now, the effect of $Z$ on demand is left unspecified.

We treat price and quantity setting in monopoly and duopoly as a black box because we are interested only in the functions determining profits in industry equilibrium (see figure 1). ${ }^{6}$ The constant marginal cost and demand curve assumptions imply that the equilibrium per capita variable profit of the monopolist, $\left(P_{M}-c_{1}\right) q_{M}$, is a function only of $W$ and $Z$. That is, it is not a function of the size of the market. Call this function $V_{M}(W, Z)$, where $V$ stands for variable. Similarly, the per capita variable profit of the second firm in a duopoly is $\left(P_{D}-c_{2}-b\right) q_{D}$. This can also be written as $V_{D}(W, Z)$, since it too does not depend on $S(Y)$. In sum, the equilibrium reduced-form profit functions depicted in figure 1 are

(1) $\Pi_{M}=V_{M}(W, Z) S(Y)-F_{1}$, and

(2) $\quad \Pi_{D}=V_{D}(W, Z) S(Y)-F_{2}-B$.

The interpretation of figure 1 is now nearly complete. Equations 1 and 2 show that profits are linear in $S$. The intercepts are clearly fixed costs. The slopes of the lines are per capita variable profits in monopoly and duopoly. What remains is the interpretation of the entry thresholds $S_{M}$ and $S_{D}$.

\section{WHAT CAN BE ESTIMATED?}

In principle, one would like to estimate the profit functions in equations 1 and 2 using data on continuous variables such as prices and quantities, but in practice such data are not readily available. Instead, all one typically has is information on the number of firms in the market. In our empirical work, estimates of equations 1 and 2 were obtained using the number of firms in the market (none, one, or two or more) as the only

6. Under the assumptions of constant marginal cost and horizontal demand shift, profits are given by $\left[P_{i}\left(q_{i}, q_{j}\right)-c_{i}\right] q_{i} S-F_{i}$. Here, $q_{i}$ and $q_{j}$ are the per capita outputs of firm $i$ and its competitor $j$. Note that the equilibrium prices associated with this profit for monopoly and for duopoly do not depend on $S$. Neither do equilibrium $q$ 's. Thus equilibrium $Q$ is proportional to $S$, as is equilibrium variable profit. 
dependent variable. As is well known, the use of limited dependent variables means that the functions $\Pi_{M}$ and $\Pi_{D}$ can be estimated only up to an unknown scale factor. ${ }^{7}$ Our economic inferences therefore must be based on ratios.

The first ratio of interest is the monopoly break-even market size, $S_{M}$, determined by the condition $\Pi_{M}=0$. Setting monopoly profits to zero implies

$$
S_{M}=F_{1} /\left(P_{M}-c_{1}\right) q_{M} .
$$

The break-even duopoly market size, $S_{D}$, is similarly determined:

$$
S_{D}=\left(F_{2}+B\right) /\left(P_{D}-c_{2}-b\right) q_{D} .
$$

The entry threshold ratio, $S_{D} / S_{M}$, is therefore

$$
\begin{aligned}
\frac{S_{D}}{S_{M}} & =\left[\frac{\left(P_{M}-c_{1}\right) q_{M}}{\left(P_{D}-c_{2}-b\right) q_{D}} \times \frac{F_{2}+B}{F_{1}}\right] \\
& =\left[\frac{\left(P_{M}-c_{1}\right) Q_{M}}{\left(P_{D}-c_{2}-b\right) Q_{D}} \times \frac{F_{2}+B}{F_{1}}\right],
\end{aligned}
$$

where the last equality follows by multiplying numerator and denominator by the same size of the market, $S$. This ratio is a combined measure of the fraction by which variable profits fall between monopoly and duopoly and the ratio of fixed costs between the first and second firm. The geometry of figure 1 illustrates this result. Underlying economic forces that shift the fixed costs of monopoly relative to dupoly move the intercepts in figure 1, while forces that shift relative variable profits change the slopes of the profit lines. It is clear from equations 3 and 5 that the entry threshold ratio keeps technological factors constant and shows the extent to which strategic factors affect entry. Equation 3 shows that the importance of fixed costs is reflected in the entry threshold for monopoly. Equation 5 summarizes the differences between a monopolist and a duopolist. This ratio can be large for several reasons that either increase the duopolist's fixed costs or lower duopoly variable profit. To discriminate between these two effects, one can compute the ratio of the firms' variable profits:

$$
S V_{M} / S V_{D}=Q_{M}\left(P_{M}-c_{1}\right) / Q_{D}\left(P_{D}-c_{2}-b\right) .
$$

7. Stephen R. Cosslett, "Distribution-Free Maximum Likelihood Estimator of the Binary Choice Model,' Econometrica, vol. 51 (May 1983), pp. 765-82. 
This is an estimate of the ratio of monopoly to duopoly variable profits and measures the fall in variable profits when competition increases.

The fall in variable profits depends on at least three important quantities: the size of entry barriers, $b$, differences in marginal costs, and the degree of competition under duopoly. ${ }^{8}$ Variable profit in a duopoly relative to that in a monopoly will be lower the higher is each of the three determinants. In the empirical work that follows, we, like others before us, cannot distinguish among these reasons as to why the ratio may be small. However, our framework does permit us to say that at least one of these factors has effects. Moreover, if one is willing to maintain particular assumptions about some of these effects, then one can discriminate among alternative theories of entry. For example, some economists believe there are no entry barriers, that all firms have the same cost function, and that both local monopolies and duopolies have the same degree of market power-none. This polar view is testable using equation 5 .

\section{STATIC AND DYNAMIC CONSIDERATIONS}

Equations 1 and 2 appear static because they relate monopoly profitability only to single-period demand and cost conditions. This raises two kinds of concerns. First, how are econometric specifications affected by expected profits changing over time? We defer this question to the next section. Second, how are monopoly profits to be interpreted, given dynamic entry-deterrence activities? This second issue arises in many contexts. For example, monopolists may expend resources to deter another firm's entry. The threat of future entry may also lead them to limit price. We interpret these to be dynamic considerations in that preentry events affect monopoly profitability.

These considerations suggest that the reduced-form monopoly profit equation 1 may be misspecified because it has no dynamic or strategic factors affecting profits; the costs to the monopolist of limit pricing, for example, do not appear in equation 1 . However, the benefits to the monopolist could show up in equation 2 in the form of higher $b$ or $B$. In fact, equation 1 is correctly specified. Preserving the advantages of

8. Product substitution also affects this ratio. See Timothy Bresnahan and Peter Reiss, "Entry in Monopoly Markets," working paper (Stanford University, Graduate School of Business, May 1987). 
incumbency may or may not cost the monopolist resources; even if it does, these costs should not appear in our estimates of the entry thresholds. This can be seen by returning to figure 1. Only when the threat of entry is substantial will a monopolist spend money to block it. The markets where the threats are greatest are those in the neighborhood of $S_{D}$. Empirical inferences about $\Pi_{M}$, however, are drawn from the threshold condition for monopoly entry. As a result, monopoly profits are inferred from the region around $S_{M}$. Thus the region in which the monopoly profit function departs from equation 1 because of entry deterrence or limit pricing expenditures is irrelevant to our inferences about $S_{M}$. Entry deterrence activities therefore affect only $S_{D}$, which is precisely what we want to have happen.

Similar arguments apply to considerations of potential entry. Potential competition (from other towns, for instance, or from firms in similar businesses in the same town) may affect monopoly pricing and profits. Again, however, it is unlikely that potential competition lowers the profit of a monopolist when that profit is just barely positive.

The only problem with our static arguments arises when entry by one firm preempts entry by another, and there is competition to be the first firm into the market. This might occur, for example, in a growing market with either natural monopoly features or with opportunities to erect barriers to entry. ${ }^{9}$ In such circumstances, $S_{M}$ will not be a nonstrategic value: firms will enter at market sizes that involve losses in order to gain the future value of the monopoly. Our interpretation of the entry threshold ratio is unaffected by this possibility since here again industries with a large ratio are characterized by strategic entry.

\section{Sample and Data}

Any empirical study of entry faces two important practical questions when passing from economic theory to data. What is the appropriate definition of a market, and what is the appropriate definition of a firm? The definition of a market is important because competition from outside the market makes it difficult to know how many competitors a firm faces.

9. Drew Fudenberg and Jean Tirole, "Preemption and Rent Equalization in the Adoption of New Technology,' Review of Economic Studies, vol. 52 (July 1985), pp. 383401. 
In theory it is easy to know what constitutes a firm, but several practical questions about the identity of real-world firms remain.

\section{MARKET DEFINITION}

There are two primary advantages to studying entry into retail trades: demand and fixed costs are localized. The geographic specificity of demand and costs suggests that in principle one could readily compute entry threshold ratios by assembling a large sample of retail markets. In practice these comparisons are not so easy because many retail markets overlap. Thus demand and cost conditions in one market may affect the ease or frequency of entry into another market. A common example of this is the suburban shopping mall that competes with downtown businesses. Although it is possible to model the effect a neighboring market has on entry, these neighborhood effects complicate theoretical and empirical models. We minimized the importance of these effects by selecting isolated markets. Our sample consisted of rural towns and cities for which we could reasonably identify surrounding areas that have few competing population centers. These markets were concentrated, and their firms typically faced little external competition. Consequently, entry by a second firm was likely to have a large impact on the conditions of competition. It also seemed likely that monopolists in these markets would have some incentive to erect entry barriers. Unfortunately, we had no information on the mechanisms that firms were likely to use to prevent entry. Moreover, we did not have information on other strategic variables, such as the prices charged by these firms or their unit sales. ${ }^{10}$ What we did have, however, was excellent information on the number of firms in the market and the size of that market.

We began with an initial sample of 149 markets (towns) drawn from our earlier study of automobile retailing. ${ }^{11}$ All counties with 1980 populations under 10,000 were used to identify counties that had distinct centers of population. We then used maps to see whether this population center was isolated. Our definition of isolated was that no other town

10. The Census Bureau suppresses information about industry sales in markets with only one or two firms. Similarly, these places are not heavily sampled in price or output indexes.

11. Bresnahan and Reiss, "Entry in Monopoly Markets." 
with a population greater than 1,000 could lie within 25 miles of the population center. This distance included towns outside the county or state but not across U.S. borders. ${ }^{12}$ Furthermore, no town or city with a population greater than 1,000 could be solarge and near that its population divided by the driving distance (up to 125 miles) from the population center was more than 600 . This ruled out, for example, towns that were within 100 miles of a city of 1 million people.

Counties that passed these tests generally had a single central town (town 1) and a surrounding area of lower population density. We counted other towns as part of town 1 if they were within two miles or otherwise close together. Counties that contained two towns or clusters of towns each with a population of 1,000 or more were usually excluded from the sample. ${ }^{13}$ Most of the 149 towns identified by these procedures were county seats concentrated in the Midwest and West.

We supplemented this initial sample with an additional 53 markets because some of the sample industries required relatively large small towns to support two firms (although all the industries had monopolies within our original sample of markets). To enlarge the sample, we searched for more towns that were isolated but not necessarily alone in their counties. To be included, the town had to be at least a forty-mile round-trip to the next town of 1,000 or more people and could not be close to an urban area. We then refined this list to get only isolated towns. In several cases there were two towns, quite far apart, in the same county; this part of the sample included relatively more Western towns.

\section{INDUSTRY SELECTION AND DEFINITIONS OF FIRMS}

In selecting geographic markets, we were careful to eliminate the possibility that nearby competitors could contaminate our inferences. In selecting the industries, we recognized and avoided a similar effect in the definition of product markets. For the empirical analysis to resemble

12. Distances are almost always measured as straight lines.

13. Information about towns was obtained from the Rand McNally Commercial Atlas (Chicago: Rand McNally, 1983); and U.S. Bureau of the Census, Census of Population, 1980, General Population Characteristics (U.S. Department of Commerce, 1982). There were four exceptions where we identified two towns close to each other and where there were no other large towns within twenty-five miles of either. Town 1 was then defined as the two towns taken together. 
the theory closely, one must be able to identify those firms in town that sell related products. Problems that arise in counting firms can best be illustrated by examples.

An example of an industry that cannot be analyzed is tobacconists. Tobacco can be sold in smoke shops, drugstores, grocery stores, gas stations, and so forth. Tracking and measuring all such outlets would be prohibitively difficult. Thus we tried to select products or trades in which product and firm definitions were fairly standard. In practice, this meant minimizing the possibility that the product was sold through unrelated or diversified retailers. As a result, a large number of manufactured goods were ruled out.

The other criterion was that an industry had to have break-even market sizes within the population ranges in our sample of towns. ${ }^{14} \mathrm{We}$ settled on thirteen retail and professional service industries: farm equipment dealers, movie theaters, new or used tire dealers, beauty shops, barbers, plumbers, electricians, new auto dealers, physicians, veterinarians, dentists, drugstores, and optometrists and opticians.

Market definition also raised an issue of what firms to include in the sample. All these industries had some competition from other kinds of firms. For instance, movie theaters sell a product that is a reasonably well defined as far as retailers are concerned. There are, of course, substitutes for movies, such as home videos, but the existence of these substitutes did not affect the analysis as long as home video stores' strategic behavior was not a major influence on the theaters. As with any good, the substitutes merely define the slope and size of the demand curve for movie houses.

Data on the presence of firms in a market were obtained from American Business Lists, a company that processes telephone books. ${ }^{15}$ From ABL we obtained a listing of each firm that advertised itself, as of June 1987, as being in a particular yellow pages "industry." To verify the listings,

14. As a practical matter, this meant we were limited to industries with between 25,000 and 200,000 firms nationwide. We added physicians and dentists despite their larger numbers because we suspected their fixed costs were like those of the automobile dealers we had already studied. We kept some industries with fewer firms, such as theaters, since we expected that they would exist in reasonable numbers in our small, isolated places despite their substantial fixed costs. Similarly, despite their greater numbers, we chose beauty shops so the sample would have an industry with very small fixed costs.

15. Much of ABL's business is selling mailing lists to the mail order industry and prospects lists to traveling salesmen. 
we checked telephone company classification schemes for ambiguous listing conventions. ${ }^{16} \mathrm{An}$ independent check was made of the automobile dealer telephone listings using manufacturers' franchise data. Finally, we visited various towns in the sample to confirm the listings. These checks convinced us that the telephone listings were remarkably accurate.

We eliminated what we considered to be duplicate firms, those with either the same name as another firm in the same town and the same industry or with the same telephone number as another firm in the same town in the same industry. ${ }^{17}$ Two listings with the same name overwhelmingly meant changes in phone numbers at the same address; these were clearly not two firms.

Listings with the same phone number but different names occurred in the professional services industries with some frequency. These were overwhelmingly group practices. For example, the phone book for Elko, Nevada, listed twelve physicians, all with the same phone number and address as the Elko Medical Clinic. We treated a group practice as a single firm. This convention affected our empirical procedures only when it resulted in a monopoly. ${ }^{18}$ Our sample would have contained six (of sixty-seven) fewer monopolies for dentists, two (of sixty-one) fewer for physicians, and no fewer monopolies for veterinarians if we had reclassified all group practices as two firms. ${ }^{19}$

A final definitional issue occurred when clinics were listed in the professional service industries. Our policy was to treat these entries as one firm. Thus, for example, when a professional and a clinic with the

16. There turned out to be even fewer classification problems in the yellow pages than we anticipated. For example, we thought that "tire retreading and repair," "tire dealernew," and "tire dealer-used" listings might need to be aggregated. In fact, all the firms in these small towns were listed as being "tire dealer-new" if they were in any of these categories. This reflects the practice of sellers of space in yellow pages as much as of purchasers of space.

17. However, the same firm can count both as a plumber and as an electrician, or as a tire dealer and as either an auto or farm equipment dealer.

18. Since we treated industries with two or more firms as duopolies, reclassifications that led to two or more firms were irrelevant, and no reclassification could lead to zero firms.

19. Three of the six pairs of dentists in group practice had the same last name. We suspected that these were husband-wife or brothers (or father-son) practices. It seemed clear that these should be classified as one firm. The treatment of the remaining group practices made essentially no difference to our estimates. 
same address and phone number were given, we counted them as one firm. When only a clinic was listed, with no separate professional listing, we also counted the clinic as one firm.

\section{NEIGHBORHOOD EFFECTS}

In constructing our sample we were careful to minimize market definition problems. However, our inferences were likely to be affected by the possibility that people living in the market may purchase some services in the next town or county. Such shoppers surely exist, especially if there is no firm in town. To take an extreme example, suppose that our towns were all only 2 miles from the next large town. Clearly it would be silly to ignore competitors in the next town. But if there were no other towns within 1,000 miles, there would be few opportunistic shopping trips. How could our sample selection rules ensure that opportunistic shoppers would be unimportant?

The existence of opportunistic shopping affects the shape of the residual demand curve facing firms in town. This curve summarizes the demand available, taking into account the arbitrage activities of customers and the supply behavior of firms in other towns. ${ }^{20}$ What we had to ensure was that residual demand in our towns was not completely flat. To see why this was necessary, consider figure 2 . First, suppose that a large fraction of local demand could easily be satisfied by low-cost shopping elsewhere. Then the residual demand curve facing the firms in any one town will be flat, and the entry of a second firm would not increase competititon. Clearly, there is a range of distances between towns, say up to $D^{*}$, for which this is the appropriate model.

As we make town 1 more and more isolated, some customers will be unwilling to shop elsewhere unless there is a substantial price advantage. The number and size of these occasions determines the slope and size of the residual demand curve. At $D^{*}$, it is profitable for firms in town 1

20. See Jonathan B. Baker and Timothy F. Bresnahan, "The Gains from Merger or Collusion in Product-Differentiated Industries," Journal of Industrial Economics, vol. 33 (June 1985), pp. 427-44, for a complete definition of the residual demand curve. David T. Scheffman and Pablo T. Spiller, "Geographic Market Definition under the U.S. Department of Justice Merger Guidelines, "Journal of Law and Economics, vol. 30 (April 1987), pp. 123-47, show that residual demand curve analysis is the appropriate means of geographical market definition when market power in local areas is at issue. 
Figure 2. Monopoly Profits as a Function of Distance to Competitive Market

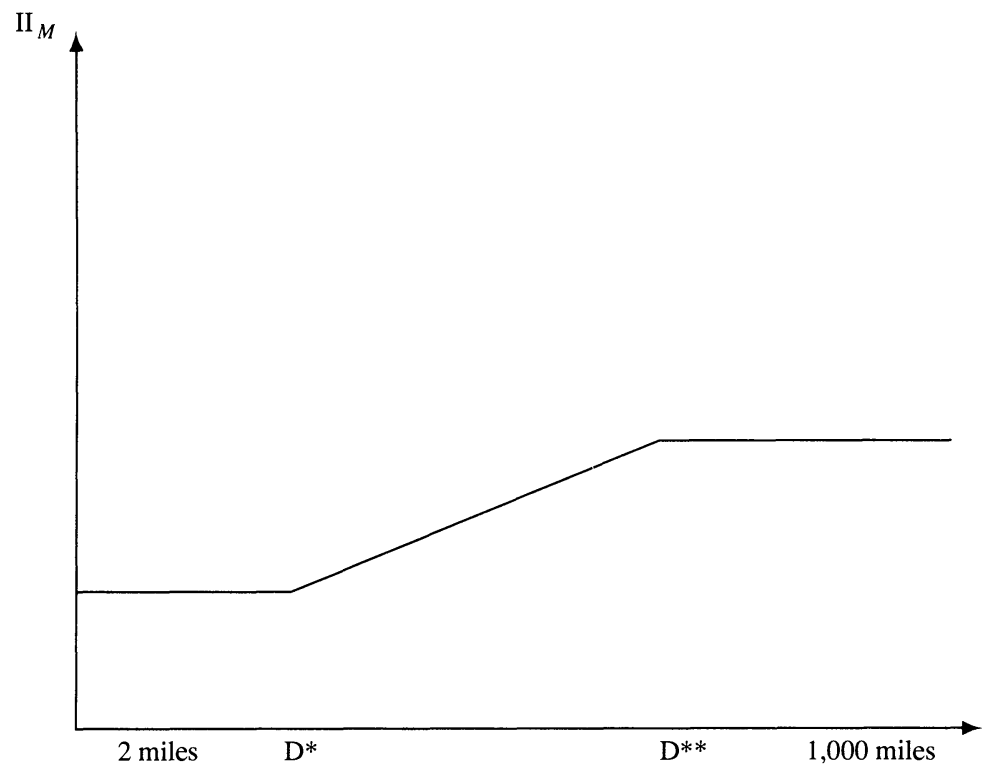

to raise prices above the competitive price. By doing this they would concede some purchases to opportunistic shoppers but would obtain prices above the competitive level on remaining purchases. Thus for distances beyond $D^{*}$ in figure 2 , the residual demand curve facing firms in town 1 would permit some market power, even taking into account the possibility of competition from outside. Obviously, as distance increases, the number of purchases made locally for any particular price increases. Thus the amount of local market power increases.

Eventually, town 1 will be so distant and isolated that there is little further increase in market power. This distance is labeled $D^{* *}$ in figure 2. Beyond this point, the residual demand curve facing firms in town 1 is unchanged, and the market can virtually be treated as a monopoly in the classic sense.

Many people in small, isolated towns doubtless make some outside purchases. ${ }^{21}$ However, it is incorrect to interpret this behavior as

21. We call this the Aunt Mathilda effect. A surprising number of economists know vivid anecdotes about a rural aunt's shopping behavior. 
evidence that markets are in the left-most part in figure 2, and that therefore local entry is not a competitive event. From $D^{*}$ to $D^{* *}$ there is local market power. We believe that our markets lie mostly in the area close to and to the right of $D^{* *}$. Later, we test this belief by including measures of distance in the definition of $S$. We use two measures of the accessibility of the next town: distance in miles and the number of people who commute to work outside the county containing town 1 .

\section{DEPENDENT VARIABLES}

Once the original list of firms was screened, we calculated how many firms there were in each market. Each industry in each town was then put into one of three categories: nonopolies, which have no firms; monopolies; and "duopolies," which have two or more (see appendix table A-1). Since the only inference we draw about duopolies is that profits for the second firm are positive, this last classification is unimportant for the inferences that follow. The industries in the sample varied substantially in the number of towns with zero, one, and two or more firms. Beauty shops, for example, were ubiquitous, with only 5 percent of the towns having none; 47 percent, however, lacked a barber.

In constructing table A-1, we worried that procedures for identifying firms might mismeasure the dependent variable by missing active firms. This could have happened if firms were listed in yellow page sections we did not track or if some were not listed at all. To explore these possibilities, we checked telephone company classification schemes for ambiguous listing conventions and found that, although the conventions do sometimes vary by telephone company, they do not vary in unusual ways. We also visited towns in our sample to verify listing conventions.

When visiting these towns, we also asked which firms in the area provided particular services to check whether we might be missing firms because the entrepreneurs did not pay business phone rates or because they relied on word of mouth instead of the yellow pages. With very few exceptions, usually instances of very recent entry or exit, the yellow pages were comprehensive. Because it was impossible to visit all towns in the sample, we also made several checks using other data sources. We checked some automobile dealer telephone listings using manufacurers' franchise records. There were no differences between our yellow page listings and these records. We also checked the accuracy of the physician listings with information from the American Medical Associ- 
ation. Their records allowed us to examine the possibility that inactive physicians were prevalent in our markets, which could have caused a problem for our firm counting convention. There were some inactive physicians in our sample counties, though they did not appear to be prevalent outside Arizona retirement areas. For the 149-place subsample in which our town was the only economic center in the county, we were able to redo our analysis based on the total number of physicians certified rather than the number in the yellow pages. This change in the definition of the dependent variable did not alter our findings.

Finally, in considering the adequacy of our definition of the dependent variable and the possibility of underreporting, we noted the prevalence of beauty shops in our sample. Only 10 of our 202 towns failed to have a yellow page listing for a beauty shop. These towns are extremely small, and their female population is even smaller. ${ }^{22}$ Even though beauticians in the smallest towns necessarily work sporadically, they use the yellow pages to advertise.

\section{MARKET SIZE VARIABLES}

Exogenous variables were divided into three classes: cost shifters, $W$, determinants of the size of the market, $Y$, and other demand shifters, $Z$. Definitions and descriptive statistics can be found in appendix table A-2.

The size of the market, $S$, is the number of effective demanders in the market. Given the diversity of the industries, the definition of a demander might vary across our industries. We always scaled $S(Y)$ to a particular unit of demand. In most cases this was the number of people living in town (TPOP), measured by the 1980 census. Of course, there is some demand from people living near but not in town; $O P O P$ is an estimate of that population. ${ }^{23}$ We give $O P O P$ a coefficient of $\lambda_{1}$ in $S($ ), to measure how important demanders out of town are relative to those in town. Some people living in town or nearby might make purchases elsewhere

22. These are basically mining and timber camps, as far as we can tell.

23. Specifically, the variable includes all population in towns within ten miles, as reported in the 1980 census or by Rand McNally. We counted all significant population in towns in the county and subtracted this from the reported census population of the county to obtain an average nontown population figure. In some cases seasonal population variations, Indian reservations, and geographical peculiarities led to minor modifications of this procedure. Under the assumption that nontown population was uniformly distributed within the county, the appropriate density outside of town and within ten miles was 
at times; OCTY measures leakages in demand by the number of people who commute to work outside of the county. This variable is included in $S$ ( ) with a coefficient of $\lambda_{2} .{ }^{24}$ The other variables in our most common specifications of $S(Y)$ recognize that market size is not a static concept. Markets that have recently decreased in size may have more firms than would be expected at their current variables. This is particularly true if firms have sunk costs in earlier, higher-demand times. Markets that have recently grown might also have fewer firms than otherwise expected if entry is a slow process. In our sample, growth or decline in one decade did seem to predict growth or decline in the next. When firms expect decreases in the size of the market, fewer will be active, while expected growth should lead to more active firms. Thus lagged growth and decline variables have complex interpretations in $S$ ( ). To capture these effects, we included the asymmetric population growth variables, $N G R W$ and $P G R W$, which are the negative and the positive parts of population growth in town 1 from 1970 to $1980 .{ }^{25}$ In most of our specifications

$$
S(Y)=T P O P+\lambda_{1} O P O P+\lambda_{2} O C T Y+\lambda_{3} N G R W+\lambda_{4} P G R W .
$$

For veterinarians and farm equipment dealers it was less obvious how the size of the market should be modeled. For veterinarians, per capita demand may be thought of in terms of numbers of people (owners of pets) plus the numbers of different kinds of farm animals. Alternatively, the demand for either veterinarians' services or those of farm equipment dealers might be predicted by the number and size of farms. For these industries we experimented with specifications that used information from the Census of Agriculture on the county population of cattle, pigs, horses, and sheep, and the number of farms in two size classes. ${ }^{26}$

computed using this residual population. Variations in this procedure, such as alternatively defining $O P O P$ as county population minus the population of town 1, made little difference for estimates of break-even market sizes.

24. In some specifications $O C T Y$ was replaced by DISTANCE, the distance in miles to the next town with a population over 1,000 .

25. Inclusion follows Hause and du Rietz, "Entry, Industry Growth, and the Microdynamics of Industry Supply." There is some question here of whether the ten-year change in town population is the relevant predictor for future market growth, but we considered twenty-year lags with little change in the results.

26. The size classes were: sales greater than $\$ 40,000$ and greater than $\$ 2,500$. Since these were countywide data, they were divided by the land area of the county in square miles. Some of the sample counties were much larger than the economic market served by the town. Using an estimate of the population density of farms or livestock made large and small counties comparable. 
For beauty shops and barber shops the variables in equation 7 were deflated by the fraction of the county population that was female or male in $1980 . .^{27}$ Thus for these two professions, size of the market has a somewhat different interpretation.

\section{OTHER DEMAND AND COST VARIABLES}

We experimented with different variables that might affect a firm's variable and fixed costs, $W$. In all our reported specifications, $W$ consisted of the per acre cost of agricultural land, FLANDVAL. This variable may capture not only the effect of land prices on fixed costs but also the effect of agricultural wealth on demand. We also experimented with wage variables, such as the average retail wage, but found the cost of land to be the most important shifter of fixed costs. Two important variables left in the constant and the error term are capital costs and the costs of the entrepreneur's or professional's own labor. The former we did not expect to vary by much in our cross-section of rural places. ${ }^{28}$ The latter was somewhat more problematic, since it was presumably a measure of the opportunity cost of an entrepreneur's time. To the extent that this varied in a way other than was captured by our covariates, our error term included these unobservable effects.

The demand shifters, $Z$, varied somewhat by industry. We also experimented with these variables and others. For every industry, we included income per capita, VPINC. For theaters, we included both the fraction of people age 65 and older, $V O L D$, and the fraction 18 and older, VNOTEEN. Here as elsewhere where we used age variables, we tried replacing them with the fraction of the adult population that was college educated, VCOLL. For tire dealers and auto dealers, we included a measure of the total farmland acreage near town, VFFARM, thinking that there might be some sales of light trucks or tires to farmers. For drugstores, physicians, dentists, and optometrists, we included the fraction of people age 65 and older, the fraction 18 and older, and the fraction born in $1980, V B I R T H S$. These variables taken together add to

27. There was little variation from the national norm in the percentage of women in the larger towns, but as previously noted, some of the small towns were essentially mining or logging camps.

28. These small firms may vary somewhat in their creditworthiness, which we left in the error term. 
a complex predictor of the health status of the population. We also added the $\log$ of heating degree days, $V \ln H E A T$, as a potential explainer of health status. This variable was so successful that we tried it in all other industries' functions as a predictor of regional taste differences.

Finally, plumbers, cooling contractors, heating contractors, and electricians provided a special problem. It seemed likely that they sold services to buildings as much as to people. An obvious candidate variable was the number of residences per capita, VHOUSES, and their average value, VHOUCST. Cooling contractor specifications also included the $\log$ of cooling degree days, $\mathrm{V} \operatorname{lnCOOL}$, and heating contractors that of heating degree days $(V \ln H E A T)$.

Given the extensive use of variables to control for other shifters in demand, we feel our interpretation of the size of the market experiment is warranted. A market twice as large represents a simple doubling of the demand curve. ${ }^{29}$ Firms in our small cities and towns operate well below the scale of those in larger areas, so that the constant marginal cost assumption is likely right. Therefore the assumptions underlying our framework of inference were satisfied for our sample, though we would be unwilling lightly to extend them to larger markets.

\section{Specification of Econometric Relations}

The discussion to this point can be summarized by writing out the equations for the profit function for monopoly and duopoly and stating the conditions for observing zero, one, or two or more firms in the market. First, if we add unknown parameters and error terms to equations 1 and 2 , we get

$$
\begin{aligned}
& \Pi_{M}=V_{M}(W, Z, \theta) \times S(Y, \lambda)-F_{1}(\gamma, W)-\epsilon_{M}, \text { and } \\
& \Pi_{D}=V_{D}(W, Z, \theta) \times S(Y, \lambda)-\left(F_{2}-B\right)(\gamma, W)-\epsilon_{D} .
\end{aligned}
$$

The form of $S(Y, \lambda)$ has already been given in equation 7 . Similarly, the variables that enter $V($ ) for each industry have also been described. To

29. This interpretation would become troubling if we were to extend the analysis toward urban areas and toward the entry of the third and fourth firms and so on. Thus the use of our techniques for determining the number of firms at which markets become effectively competitive will require further thought. 
simplify estimation, we assumed that $V()$, the equilibrium per capita variable profit, is linear in cost and demand variables:

$$
\begin{aligned}
& V_{M}(W, Z, \theta)=V P O+\Sigma_{k} \theta_{k} Z_{k}, \text { and } \\
& V_{D}(W, Z, \theta)=V P O-V P D+\Sigma_{k} \theta_{k} Z_{k} \cdot{ }^{30}
\end{aligned}
$$

Equations 8 and 10 show that the coefficient of the lead market-size variable, usually $T P O P$, is $V P O$ and $\theta_{k}$ is the coefficient of the $Z_{k}$ variable in $\Pi_{M}$. Similarly, $T P O P$ has coefficient $V P O-V P D$ in $\Pi_{D}$. Further, equations 8 and 10 imply that TPOP interacts with all of the variables in variable profits. In our tables, variables in $V_{M}$ and $V_{D}$ begin with the letter $V$.

In most specifications we also assumed that fixed costs varied among dealers in the same way. Specifically, these differences are assumed to be linear in the factor prices. ${ }^{31}$

$$
\begin{aligned}
F_{1} & =F I X O+\gamma_{W} R E T W A G+\gamma_{L} F L A N D V A L, \\
F_{2}+B & =F I X O+F I X D+\gamma_{W} R E T W A G+\gamma_{L} F L A N D V A L .
\end{aligned}
$$

In both the variable cost function and the fixed cost function, the constant terms differ for monopolies and duopolies. The difference, $V P D$, measures the fall in variable profit due to entry. The difference in the fixed cost intercepts, FIXD, measures heterogeneity in fixed costs or entry barriers of the $B$ form.

The introduction of error permits the construction of a likelihood function:

$$
\begin{aligned}
P_{0}=\operatorname{Pr}(0 \text { firms }) & =\operatorname{Pr}\left(\Pi_{M}<0\right), \\
P_{1}=\operatorname{Pr}(1 \text { firm }) & =\operatorname{Pr}\left(\Pi_{M} \geq 0 \text { and } \Pi_{D} \leq 0\right), \text { and } \\
P_{2}=\operatorname{Pr}(2 \text { firms }) & =\operatorname{Pr}\left(\Pi_{D}>0\right) .
\end{aligned}
$$

In all the results reported in our tables, $\epsilon_{D}=\epsilon_{M}$, and the errors are normal. Thus these specifications are ordered probits. In work not

30. We tried nonlinear specifications for variable profits-without much success.

31. The linear functional forms for fixed costs and variable profit are not implied by the theory, since a change in the functional form of the error (say from probit to logit) could be offset by a transformation of the profit function. However, the linearity was not crucial to our interpretation. Instead, we used the linearity of $\Pi$ in $S$ only to obtain reducedform interpretations of the entry thresholds. 
reported here, we have experimented with alternative assumptions about the error terms. ${ }^{32}$

Tables 1 and 2 estimate specifications for the industries. ${ }^{33}$ There are few surprises in the coefficients of $Z$ and $W$ variables (those prefixed $V$ in the table and FLANDVAL) and we have little to say about them. It was our intention to include too many variables in this part of the function so as to avoid the bias of left-out variables in our estimates of the marketsize coefficients. Given that these variables are largely insignificant, the tendency would be to remove rather than add them. Thus there is little evidence for any remaining omitted-variable bias.

$N G R W$ and $P G R W$ are difficult to interpret in the best of circumstances. In our data, where the endogenous variable is measured in 1987 and most of the exogenous variables are measured in the previous (1980) census, these variables are particularly hard to interpret. The lagged pattern of growth is predicting growth both before and after the date we observed the endogenous variable. Thus the variables have not only the Hause and du Rietz interpretation, but also a more elementary one of predicting demand at the time we observed it. ${ }^{34}$

\section{Results for Individual Industries}

For clarity, we discuss results by topic rather than by industry. The tables divide the industries into a "professional" services group and a "retail" group.

\section{ENTRY THRESHOLD RATIOS}

The parameters of most immediate interest are the differences between monopoly and duopoly variable profits and fixed costs. The

32. See Bresnahan and Reiss, "Entry in Monopoly Markets." Our other specifications were probitlike. One let $\epsilon_{M}$ be the maximum of two correlated normals, while $\epsilon_{D}$ was their minimum. This gave a greater self-selection flavor to monopoly versus duopoly entry. Another specification made $\epsilon_{D}$ smaller than $\epsilon_{M}$ by the value of one-half normal random variable. This also permitted a greater tendency for monopoly profit to be random. We also considered heteroskedastic probits, with the variance depending on $S$. Since these specifications made little difference and were bulky, we have suppressed them here.

33. No results are presented for beauty shops, which were so frequent in the sample that $S_{M}$ could not be estimated with any reliability.

34. Hause and du Rietz, "Entry, Industry Growth, and the Microdynamics of Industry Supply." 
Timothy F. Bresnahan and Peter C. Reiss

Table 1. Parameter Estimates for "Professional" Industries

\begin{tabular}{|c|c|c|c|c|c|c|}
\hline $\begin{array}{c}\text { Independent } \\
\text { variable }\end{array}$ & $\begin{array}{l}\text { Physi- } \\
\text { cians }\end{array}$ & Dentists & $\begin{array}{l}\text { Veteri- } \\
\text { narians }\end{array}$ & $\begin{array}{l}\text { Drug- } \\
\text { stores }\end{array}$ & $\begin{array}{l}\text { Optom- } \\
\text { etrists }\end{array}$ & $\begin{array}{c}\text { Auto } \\
\text { dealers }\end{array}$ \\
\hline$O P O P$ & $\begin{array}{r}-0.141 \\
(0.585)\end{array}$ & $\begin{array}{r}-0.451 \\
(0.455)\end{array}$ & $\begin{array}{c}-0.778 \\
(0.408)\end{array}$ & $\begin{array}{c}-0.528 \\
(0.273)\end{array}$ & $\begin{array}{c}-0.405 \\
(0.437)\end{array}$ & $\begin{array}{c}0.437 \\
(0.824)\end{array}$ \\
\hline$N G R W$ & $\begin{array}{r}-1.108 \\
(1.395)\end{array}$ & $\begin{array}{r}-0.429 \\
(1.017)\end{array}$ & $\begin{array}{c}-0.982 \\
(1.783)\end{array}$ & $\begin{array}{r}-0.822 \\
(0.931)\end{array}$ & $\begin{array}{c}-1.633 \\
(1.388)\end{array}$ & $\begin{array}{c}2.435 \\
(0.879)\end{array}$ \\
\hline PGRW & $\begin{array}{c}2.045 \\
(1.359)\end{array}$ & $\begin{array}{c}1.899 \\
(1.084)\end{array}$ & $\begin{array}{c}-0.705 \\
(0.555)\end{array}$ & $\begin{array}{c}0.612 \\
(0.714)\end{array}$ & $\begin{array}{c}-0.347 \\
(0.472)\end{array}$ & $\begin{array}{c}-0.107 \\
(0.375)\end{array}$ \\
\hline$O C T Y$ & $\begin{array}{r}-0.519 \\
(0.420)\end{array}$ & $\begin{array}{c}0.278 \\
(0.984)\end{array}$ & $\begin{array}{c}2.068 \\
(1.365)\end{array}$ & $\begin{array}{r}-0.108 \\
(0.198)\end{array}$ & $\begin{array}{c}3.317 \\
(1.343)\end{array}$ & $\begin{array}{c}0.796 \\
(1.099)\end{array}$ \\
\hline$V P O$ & $\begin{array}{c}1.981 \\
(0.935)\end{array}$ & $\begin{array}{r}-2.262 \\
(0.858)\end{array}$ & $\begin{array}{r}-1.115 \\
(0.421)\end{array}$ & $\begin{array}{r}-0.343 \\
(0.975)\end{array}$ & $\begin{array}{r}-1.690 \\
(0.500)\end{array}$ & $\begin{array}{r}-0.762 \\
(1.299)\end{array}$ \\
\hline$V P D$ & $\begin{array}{c}0.340 \\
(0.188)\end{array}$ & $\begin{array}{c}0.179 \\
(0.231)\end{array}$ & $\begin{array}{c}0.102 \\
(0.106)\end{array}$ & $\begin{array}{c}0.169 \\
(0.271)\end{array}$ & $\begin{array}{c}0.360 \\
(0.125)\end{array}$ & $\begin{array}{c}0.181 \\
(0.217)\end{array}$ \\
\hline FIXO & $\begin{array}{c}1.095 \\
(0.311)\end{array}$ & $\begin{array}{c}1.237 \\
(0.334)\end{array}$ & $\begin{array}{c}0.281 \\
(0.302)\end{array}$ & $\begin{array}{c}1.153 \\
(0.333)\end{array}$ & $\begin{array}{c}1.801 \\
(0.296)\end{array}$ & $\begin{array}{c}0.865 \\
(0.289)\end{array}$ \\
\hline FIXD & $\begin{array}{c}0.818 \\
(0.287)\end{array}$ & $\begin{array}{c}1.668 \\
(0.381)\end{array}$ & $\begin{array}{c}1.287 \\
(0.261)\end{array}$ & $\begin{array}{c}1.733 \\
(0.402)\end{array}$ & $\begin{array}{c}1.206 \\
(0.363)\end{array}$ & $\begin{array}{c}0.832 \\
(0.304)\end{array}$ \\
\hline VOLD & $\begin{array}{c}0.540 \\
(0.334)\end{array}$ & $\begin{array}{c}0.826 \\
(0.503)\end{array}$ & $\ldots$ & $\begin{array}{c}2.569 \\
(0.508)\end{array}$ & $\begin{array}{c}0.291 \\
(0.150)\end{array}$ & $\ldots$ \\
\hline VNOTEEN & $\cdots$ & $\ldots$ & $\ldots$ & $\ldots$ & $\ldots$ & $\begin{array}{c}0.414 \\
(1.664)\end{array}$ \\
\hline VLANDVAL & $\ldots$ & $\cdots$ & $\begin{array}{c}0.833 \\
(0.345)\end{array}$ & $\cdots$ & $\cdots$ & $\ldots$ \\
\hline VBIRTHS & $\begin{array}{c}3.136 \\
(2.188)\end{array}$ & $\begin{array}{r}-0.028 \\
(1.803)\end{array}$ & $\ldots$ & $\begin{array}{r}-4.042 \\
(1.748)\end{array}$ & $\begin{array}{r}-1.117 \\
(0.558)\end{array}$ & $\cdots$ \\
\hline VCOLL & $\ldots$ & $\ldots$ & $\ldots$ & $\ldots$ & $\cdots$ & $\begin{array}{c}1.386 \\
(3.459)\end{array}$ \\
\hline VFFARM & $\cdots$ & $\ldots$ & $\begin{array}{c}0.061 \\
(0.080)\end{array}$ & $\cdots$ & $\cdots$ & $\cdots$ \\
\hline VPINC & $\begin{array}{r}-0.027 \\
(0.046)\end{array}$ & $\begin{array}{c}0.040 \\
(0.061)\end{array}$ & $\begin{array}{c}0.045 \\
(0.026)\end{array}$ & $\begin{array}{c}0.020 \\
(0.061)\end{array}$ & $\begin{array}{c}0.017 \\
(0.028)\end{array}$ & $\begin{array}{r}-0.001 \\
(0.074)\end{array}$ \\
\hline$V \ln H E A T$ & $\begin{array}{r}-0.145 \\
(0.103)\end{array}$ & $\begin{array}{c}0.345 \\
(0.107)\end{array}$ & $\begin{array}{c}0.128 \\
(0.049)\end{array}$ & $\begin{array}{c}0.122 \\
(0.116)\end{array}$ & $\begin{array}{c}0.280 \\
(0.068)\end{array}$ & $\begin{array}{c}0.175 \\
(0.117)\end{array}$ \\
\hline VFLANDVAL & $\begin{array}{r}-1.375 \\
(0.557)\end{array}$ & $\begin{array}{r}-1.020 \\
(0.581)\end{array}$ & $\begin{array}{c}0.892 \\
(0.966)\end{array}$ & $\begin{array}{r}-0.567 \\
(0.530)\end{array}$ & $\begin{array}{r}-0.425 \\
(0.466)\end{array}$ & $\begin{array}{r}-0.136 \\
(0.537)\end{array}$ \\
\hline Log likelihood & 137.083 & 103.805 & 160.387 & 99.444 & 142.181 & 126.236 \\
\hline
\end{tabular}

Source: Authors' calculations. See text description and table A-2.

a. Standard errors are in parentheses.

intercept of monopoly fixed costs is $F I X 0$, and that of monopoly variable profit, VPO. There is a systematic pattern in which FIXD is large when compared to FIXO; that is, the estimated $F_{2}+B$ is much larger than $F_{1}$. The difference between duopoly and monopoly variable profit, however, is not significant in most industries. In three industries in table 2, we even had to constrain $V P D$ to be zero to avoid predicting monopoly profit less than duopoly profit. ${ }^{35}$

35. The estimation procedures, as well as the economic logic, are adversely affected if this constraint fails. See Bresnahan and Reiss, "Entry in Monopoly Markets." 


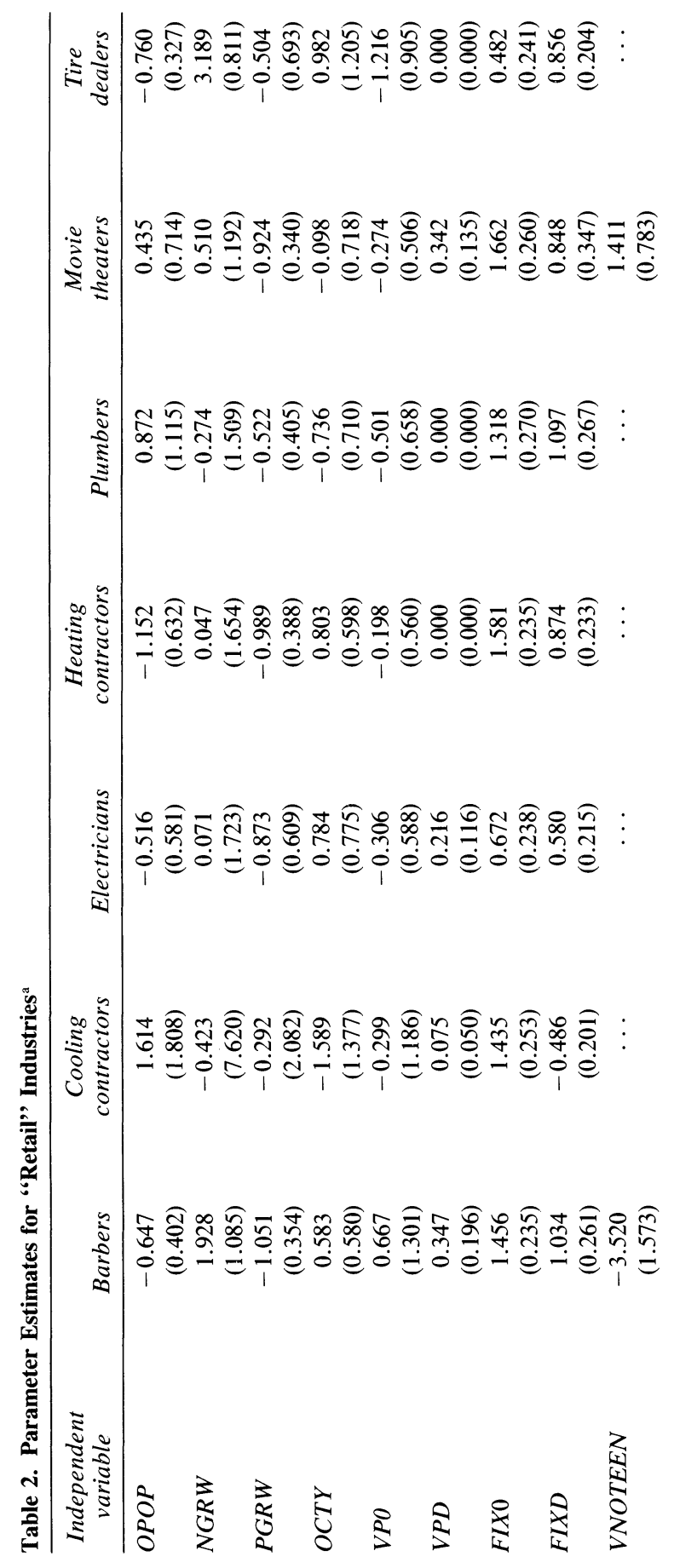




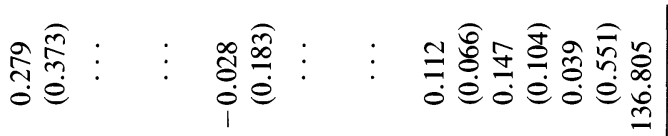

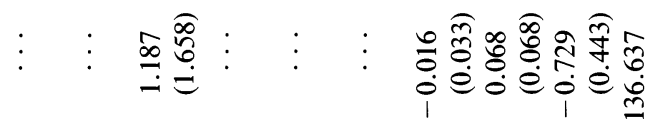

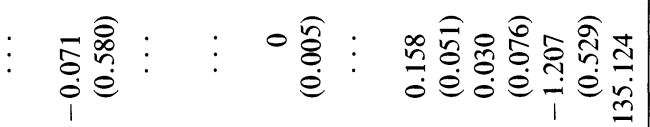

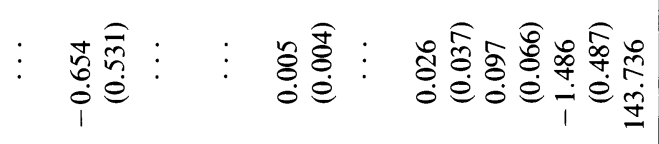

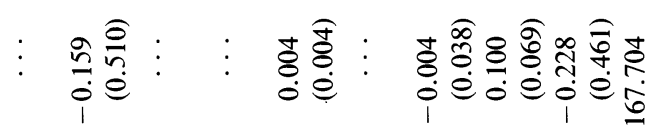

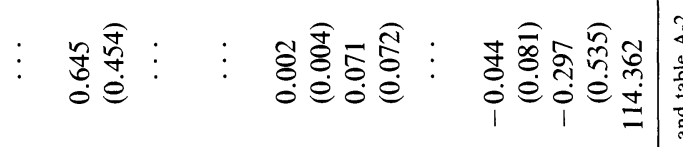

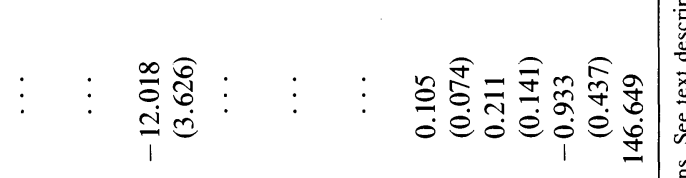

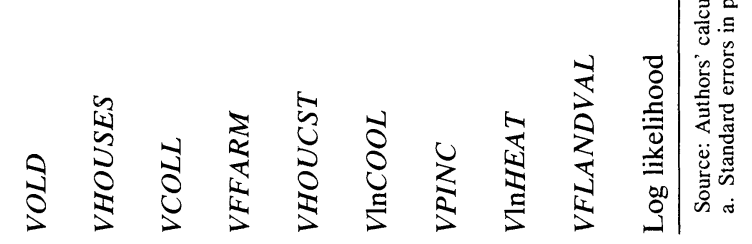


The estimates for the professional industries are interpreted in table 3, which shows break-even market sizes and related statistics. All the statistics in the table are reported at two points. At the first of these, $Z$ and $W$ are evaluated at the mean values for monopolies in each industry (denoted by $X_{M}$ ). At the second, $Z$ and $W$ are evaluated at their overall sample mean $\left(X_{T}\right)$. The first of these is our preferred measure; it evaluates the function at both the margin between no firm and one firm and the margin between one firm and two. We added the second primarily to check if there was any important variation within our sample in the economic inferences.

The first row of table 3 shows that the town size needed to support a single firm varies widely among professional industries. As one would expect, it takes far fewer people to support a doctor or dentist than to support an optician. Similarly, the second row indicates substantial variation in size of the market needed to support a duopoly. Comparing the $X_{M}$ figures with the $X_{T}$ figures, we note that the point in $(Z, W)$ space at which the functions are evaluated matters for some industries (notably physicians). The point at which functions are evaluated, however, is basically irrelevant to the calculations for most industries. For most of these industries, then, the effect of $(Z, W)$ in shifting the profit functions is economically insignificant despite the statistical significance of some variables. Probably as a result of this, experiments that included different variables have little impact on our economic inferences. ${ }^{36}$

The entry threshold ratios vary significantly among these industries. Auto dealers are an extreme case, as we suspected. They have by far the narrowest range of monopolies, requiring a market only 2.3 times larger to support a second firm. Veterinarians are at the other extreme, requiring a market more than 4 times as large. The remaining industries, physicians, dentists, druggists, and opticians, are remarkably similar on this measure: each takes roughly 3 times as large a market to support a second firm.

Table 4 gives the comparable figures for retail industries. Many of the

36. By experiments with the specification, we mean changes in the list of covariates in $(Z, W)$ for all these industries (in results not reported here but available from us). For auto dealers we also mean very extensive experimentation with the assumptions about the error term and the model reported in Bresnahan and Reiss, "Entry in Monopoly Markets." By economic inferences, we mean inferences about the ratio of break-even market sizes and about the ratio of monopoly to duopoly variable profits. 
Table 3. Entry Thresholds for "Professional" Industries

\begin{tabular}{lcccccc}
\hline Variable & Physicians & Dentists & $\begin{array}{c}\text { Veteri- } \\
\text { narians }\end{array}$ & $\begin{array}{c}\text { Drug- } \\
\text { stores }\end{array}$ & $\begin{array}{c}\text { Opti- } \\
\text { cians }\end{array}$ & $\begin{array}{c}\text { Auto } \\
\text { dealers }\end{array}$ \\
\hline$S_{M}\left(X_{M}\right)$ & 730 & 722 & 1,000 & 583 & 1,886 & 664 \\
$S_{D}\left(X_{M}\right)$ & 2,463 & 2,304 & 4,256 & 1,778 & 5,481 & 1,538 \\
$S_{M}\left(X_{T}\right)$ & 552 & 632 & 1,008 & 467 & 1,885 & 664 \\
& $(153)$ & $(173)$ & $(277)$ & $(101)$ & $(282)$ & $(135)$ \\
$S_{D}\left(X_{T}\right)$ & 1,659 & 1,999 & 4,189 & 1,400 & 5,447 & 1,538 \\
& $(297)$ & $(355)$ & $(2,219)$ & $(129)$ & $(871)$ & $(173)$ \\
$S_{D} / S_{M}\left(X_{M}\right)$ & 3.378 & 3.195 & 4.255 & 3.040 & 2.907 & 2.315 \\
$S_{D} / S_{M}\left(X_{T}\right)$ & 3.012 & 3.164 & 4.149 & 2.994 & 2.890 & 2.315 \\
& $(1.07)$ & $(.695)$ & $(2.565)$ & $(.663)$ & $(.289)$ & $(.364)$ \\
$V_{D} / V_{M}\left(X_{M}\right)$ & .644 & .864 & .807 & .901 & .593 & .631 \\
$V_{D} / V_{M}\left(X_{T}\right)$ & .728 & .879 & .810 & .920 & .595 & .631 \\
& $(.466)$ & $(.508)$ & $(3.538)$ & $(.223)$ & $(1.93)$ & $(.430)$ \\
\hline
\end{tabular}

Source: Authors' calculations. See text description.

a. Standard errors in parentheses.

b. $X_{M}$ refers to evaluation at monopoly means of $Z$ and $W, X_{T}$ to evaluation at sample means of $Z$ and $W$.

ETRs are smaller than was typical of the professional industries. That for heating contractors is below 2, and those of all but electrical contractors, movie theaters, and tire dealers are below 2.7. Further, only the electrical contractors' is estimated with any real accuracy.

Appendix table A-1 shows the number of firms by market size for each industry. The table cannot, of course, hold constant the influence of variables other than town population, but it does make clear that the boundaries between the regions where there tend to be no, one, or two

Table 4. Entry Thresholds for "Retail"' Industries a

\begin{tabular}{lccccccc}
\hline Variable $^{\mathrm{b}}$ & Barbers & $\begin{array}{c}\text { Cooling } \\
\text { contractors }\end{array}$ & $\begin{array}{c}\text { Electri- } \\
\text { cians }\end{array}$ & $\begin{array}{c}\text { Heating } \\
\text { contractors }\end{array}$ & Plumbers & $\begin{array}{c}\text { Movie } \\
\text { theaters }\end{array}$ & $\begin{array}{c}\text { Tire } \\
\text { dealers }\end{array}$ \\
\hline$S_{M}\left(X_{M}\right)$ & 941.9 & 6958 & 1057 & 3014 & 1559 & 1985 & 618 \\
$S_{D}\left(X_{M}\right)$ & 2534.9 & 15313 & 3292 & 5315 & 3311 & 6000 & 1690 \\
$S_{M}\left(X_{T}\right)$ & 1003.8 & 8285 & 1040 & 3168 & 1507 & 1982 & 563 \\
& $(118)$ & $(3290)$ & $(244)$ & $(419)$ & $(207)$ & $(231)$ & $(223)$ \\
$S_{D}\left(X_{T}\right)$ & 2672.1 & 20831 & 3242 & 5589 & 3226 & 5909 & 1539 \\
& $(1259.8)$ & $(15195)$ & $(473)$ & $(2110)$ & $(340)$ & $(3927)$ & $(621)$ \\
$S_{D} / S_{M}\left(X_{M}\right)$ & 2.692 & 2.201 & 3.112 & 1.763 & 2.125 & 3.022 & 2.731 \\
$S_{D} / S_{M}\left(X_{T}\right)$ & 2.662 & 2.515 & 3.114 & 1.764 & 2.140 & 2.981 & 2.732 \\
& $(1.209)$ & $(1.091)$ & $(0.677)$ & $(0.591)$ & $(0.267)$ & $(1.94)$ & $(1.448)$ \\
$V_{D} / V_{M}\left(X_{T}\right)$ & 0.710 & 0.617 & 0.626 & 1.000 & 1.000 & 0.532 & 1.000 \\
& $(1.946)$ & $(551.0)$ & $(5.770)$ & $\ldots$ & $\ldots$ & $(3.80)$ & $\ldots$ \\
\hline
\end{tabular}

Source: Authors' calculations. See text description.

a. Standard errors in parentheses.

b. $X_{M}$ refers to evaluation at monopoly means of $Z$ and $W, X_{T}$ to evaluation at sample means of $Z$ and $W$. 
or more firms are clearly defined. Further, it suggests ETRs that are large in exactly those industries for which we have estimated large ratios.

Our experiments with the definition of $S(Y)$ for the veterinarians and farm equipment sales are given in tables 5 and 6 . For the veterinarians, we report three more specifications. In the first column, $S(Y)$ is FARMS40/ TPOP $\left(T P O P+\lambda_{1} O P O P+\lambda_{2} O C T Y+\lambda_{3} N G R W+\lambda_{4} P G R W\right)$, so that the lead term in $S()$ is the number of farms with sales over $\$ 40,000$. In the second column the lead term is TPOP, just as in the earlier tables; however, horses and cows per square mile are included in $S$. In the third column the lead term is still TPOP, and all of the other variables in $S(Y)$ are animals per square mile. It is clear from the likelihoods that a blend specification involving both TPOP and some measure of the importance of large farm animals is best at predicting the number of active veterinarians. The entry threshold ratio appears somewhat specificationdependent. The overall effect of these changes in specification is to lower the estimated ETR, making veterinarians less unusual among professions.

\section{DECOMPOSITION}

Like all discrete dependent variable methods, ours can estimate only the parameters of the profit functions up to scale. This is not troubling, since all the interesting statistics are ratios of parameters. The quantities, $S$, are themselves ratios of parameters, and it is obvious that $V_{D} / V_{M}$ is unchanged when the functions are rescaled. Even ratios, however, may be somewhat dependent on functional form, as the literature on semiparametric inference emphasizes. ${ }^{37}$

These econometric points lead to another attractive feature of estimating $S_{D} / S_{M}$ : the information in the data that led to an inference about this quantity was clear. When the interval of market sizes that typically have monopoly is wide, the estimated ETR will be large. Given the importance of the size of the market as an explainer of the number of firms, the width of the typical monopoly market-size interval is largely determined by data rather than by econometric specification. However, our decomposition of $S_{D} / S_{M}$ into fixed and variable profits factors (following equation 5) cannot be so lightly defended. It may well be affected by functional form assumptions about the error distribution.

37. Cosslett, "Distribution-Free Maximum Likelihood Estimator." 
Timothy F. Bresnahan and Peter C. Reiss

Table 5. Incidence of Veterinarians ${ }^{a}$

\begin{tabular}{|c|c|c|c|}
\hline \multirow{2}{*}{$\begin{array}{l}\text { Independent } \\
\text { variable }\end{array}$} & \multicolumn{3}{|c|}{ Coefficients } \\
\hline & 1 & 2 & 3 \\
\hline$O P O P$ & $\begin{array}{c}-2.070 \\
(1.271)\end{array}$ & $\ldots$ & $\ldots$ \\
\hline$N G R W$ & $\begin{array}{c}-3.234 \\
(5.645)\end{array}$ & $\begin{array}{c}-0.567 \\
(1.750)\end{array}$ & $\cdots$ \\
\hline$P G R W$ & $\begin{array}{l}10.383 \\
(8.101)\end{array}$ & $\begin{array}{c}-0.361 \\
(0.643)\end{array}$ & $\ldots$ \\
\hline$O C T Y$ & $\begin{array}{c}0.519 \\
(0.578)\end{array}$ & $\ldots$ & $\ldots$ \\
\hline HORSES & $\ldots$ & $\begin{array}{c}1.374 \\
(0.794)\end{array}$ & $\begin{array}{l}1.255 \\
(0.795)\end{array}$ \\
\hline COWS & $\ldots$ & $\begin{array}{l}1.970 \\
(1.157)\end{array}$ & $\begin{array}{l}2.186 \\
(1.25)\end{array}$ \\
\hline$P I G S$ & $\ldots$ & $\ldots$ & $\begin{array}{r}0.137 \\
(1.894)\end{array}$ \\
\hline SHEEP & $\ldots$ & $\ldots$ & $\begin{array}{c}0.004 \\
(0.016)\end{array}$ \\
\hline$V P 0$ & $\begin{array}{c}6.701 \\
(8.448)\end{array}$ & $\begin{array}{c}-0.525 \\
(0.386)\end{array}$ & $\begin{array}{r}-0.449 \\
(0.335)\end{array}$ \\
\hline$V P D$ & $\begin{array}{c}1.337 \\
(1.139)\end{array}$ & $\begin{array}{c}0.255 \\
(0.106)\end{array}$ & $\begin{array}{r}0.274 \\
(0.101)\end{array}$ \\
\hline FIXO & $\begin{array}{c}0.357 \\
(0.267)\end{array}$ & $\begin{array}{l}1.112 \\
(0.378)\end{array}$ & $\begin{array}{l}1.10 \\
(0.384)\end{array}$ \\
\hline FIXD & $\begin{array}{c}0.973 \\
(0.216)\end{array}$ & $\begin{array}{c}0.769 \\
(0.333)\end{array}$ & $\begin{array}{c}0.697 \\
(0.331)\end{array}$ \\
\hline$V L A N D V A L$ & $\begin{array}{l}1.170 \\
(2.512)\end{array}$ & $\begin{array}{c}0.387 \\
(0.260)\end{array}$ & $\begin{array}{c}0.415 \\
(0.248)\end{array}$ \\
\hline VFFRAC & $\begin{array}{c}-1.525 \\
(1.471)\end{array}$ & $\begin{array}{c}-0.046 \\
(0.078)\end{array}$ & $\begin{array}{r}-0.048 \\
(0.073)\end{array}$ \\
\hline VPINC & $\begin{array}{c}0.874 \\
(0.519)\end{array}$ & $\begin{array}{c}0.042 \\
(0.022)\end{array}$ & $\begin{array}{c}0.035 \\
(0.018)\end{array}$ \\
\hline$V \ln H E A T$ & $\begin{array}{c}-0.862 \\
(0.890)\end{array}$ & $\begin{array}{c}0.091 \\
(0.044)\end{array}$ & $\begin{array}{c}0.085 \\
(0.039)\end{array}$ \\
\hline FLANDVAL & $\begin{array}{c}-0.411 \\
(0.557)\end{array}$ & $\begin{array}{c}-0.037 \\
(0.753)\end{array}$ & $\begin{array}{r}0.059 \\
(0.753)\end{array}$ \\
\hline Log likelihood & -182.421 & -155.10 & -155.31 \\
\hline$S_{D} / S_{M}$ & $\begin{array}{c}7.94 \\
(0.710)\end{array}$ & $\begin{array}{c}3.012 \\
(1.130)\end{array}$ & $\begin{array}{r}3.064 \\
(1.110)\end{array}$ \\
\hline
\end{tabular}

Source: Authors' calculations. See text description and table A-2.

a. Standard error's are in parentheses.

Tables 3 and 4 show the ratio of duopoly to monopoly variable profits. There are several problems with these statistics. We have already suggested that the decomposition will depend more on the functional form of the error (be less robust) than will the ETRs themselves. Further, 
Table 6. Incidence of Farm Equipment Dealers ${ }^{a}$

\begin{tabular}{lc||cc}
\hline $\begin{array}{c}\text { Independent } \\
\text { variable }\end{array}$ & Coefficients & $\begin{array}{c}\text { Independent } \\
\text { variable }\end{array}$ & Coefficients \\
\hline OFARM & -0.888 & FIXD & 0.573 \\
& $(0.221)$ & & $(0.221)$ \\
NGRW & -1.400 & VLANDVAL & 12.034 \\
& $(1.498)$ & & $(7.291)$ \\
PGRW & 1.615 & VFFRAC & 4.735 \\
& $(1.246)$ & & $(2.502)$ \\
NFARMS2 & 0.058 & VPINC & 0.057 \\
& $(0.108)$ & & $(0.656)$ \\
VPO & 11.598 & VInHEAT & -1.006 \\
& $(17.256)$ & & $(1.755)$ \\
VPD & -1.330 & FLANDVAL & 0.053 \\
& $(1.476)$ & & $(0.764)$ \\
FIXO & 1.138 & Log likelihood & -154.102 \\
& $(0.307)$ & $S_{D} / S_{M}$ & 1.726 \\
& & & $(0.131)$ \\
\hline
\end{tabular}

Source: Authors' calculations. See text description.

a. Standard errors in parentheses.

we note from the tables that the ratios of the variable profits are imprecisely estimated, even given our functional form. For three industries we cannot estimate them at all. Thus any interpretation of the decomposition will be very tentative. ${ }^{38}$

The most obvious regularity in the estimates of $V_{D} / V_{M}$ is that they exceed 0.5 , sometimes substantially. Since in an industry without product differentiation this ratio must be less than or equal to 0.5 , the excess is striking. ${ }^{39} \mathrm{Few}$ of these ratios were precisely estimated, so that it was not possible to reject 0.5 . Nonetheless, the point estimates implied (following the logic of the decomposition) that $F_{2}+B>F_{1}$. That is, simply reading the decomposition literally would assign most of the difference between monopoly and duopoly profits to the fixed costs portion, not to a fall in variable profits.

38. The primary reason for not reporting nonprobit specifications can now be stated. Even when we made strong functional form assumptions, the decomposition was imprecisely estimated. Thus the value of exploring the even greater imprecision that can be obtained by making weaker assumptions was small. Based on our substantial experiments with the auto dealer case, it is likely that experimentation with the kinds of error structures described in note 32 would change the point estimates of $V_{D} / V_{M}$ substantially. It is unlikely that such experimentation would alter the estimated ETRs.

39. Even if there is no increase in competition between monopoly and duopoly, $V_{D}$ should be only $0.5 \times V_{M}$ in such industries; then the two firms' variable profits will sum to monopoly profits. 
Of course, a decrease in variable profits can arise if there is substantial product differentiation, which will have two effects. First, the second firm will broaden the customer base by offering a second product, and second, behavior is likely to be less competitive when firms sell slightly different products. Our conclusion is tentatively that duopolies are not particularly competitive in these industries, possibly because of the existence of product differentiation.

\section{MARKET DEFINITION TESTS}

If the variable $O C T Y$ were consistently negative and significant we would infer that there is a leakage problem with our market definition. Consider the coefficient in the physicians column of table 1, which shows that every out-of-county commuter means one-half $(0.519)$ fewer customers for physicians in town. This is not an implausible level for this variable. It certainly does not suggest that those areas economically connected to neighboring areas (as measured by commuting) have dramatically more competition from outside. Most of the $O C T Y$ coefficients are like this: smaller than 1.0 in absolute value and insignificant. The two times in table 1 that $O C T Y$ does turn up large and reasonably precisely estimated (for veterinarians and optometrists) it is positive. The one large (if insignificant) negative coefficient occurs for the cooling contractors. These estimates, mostly small numbers, imprecisely estimated, and varying among industries, do not seem to suggest that we have any important problems of geographic market definition.

Further evidence on the accuracy of market definition can be found in table 7, which uses what we call the unisolated sample to estimate the model for physicians and dentists. ${ }^{40}$ This sample consisted of 194 counties with populations under 10,000 . It met the selection criteria for our 149county subsample, except that town 1 was not required to be geographically isolated. In the unisolated sample, $O C T Y$ is large, negative, and significant for both professions. This means that markets that have a large number of out-of-county commuters systematically have fewer firms.

This additional finding can be interpreted to place our regular sample in the context of figure 2 . In the regular sample of isolated places, there

40. The dependent variable here is the American Medical Association or American Dental Association count of certified practitioners that we described earlier. 
Table 7. Effects of Population Variables on Number of Physicians and Dentists, "Unisolated" Sample ${ }^{a}$

\begin{tabular}{ccc}
\hline $\begin{array}{c}\text { Independent } \\
\text { variable }\end{array}$ & Physicians & Dentists \\
\hline OPOP & .447 & .773 \\
& $(.123)$ & $(.151)$ \\
NGRW & .169 & -.773 \\
& $(.561)$ & $. .694)$ \\
PGRW & -.035 & -.401 \\
& $(.245)$ & $(.238)$ \\
OCTY & -2.069 & -2.690 \\
& $(.748)$ & $(.885)$ \\
VPO & .848 & .550 \\
& $(.214)$ & $(.108)$ \\
$V P D$ & 0 & 0 \\
& $(0)$ & $(0)$ \\
FIXO & .803 & 1.064 \\
& $(.281)$ & $(.260)$ \\
FIXD & .882 & 1.363 \\
& $(.352)$ & $(.351)$ \\
$S_{M}\left(X_{T}\right)$ & 947 & 1,936 \\
& $(220)$ & $(310)$ \\
$S_{D}\left(X_{T}\right)$ & 1,988 & 4,415 \\
& $(1,078)$ & $(.486)$ \\
$S_{D} / S_{M}$ & 2.099 & 2.280 \\
& $(.546)$ & $(.126)$ \\
\hline
\end{tabular}

Source: Authors' calculations. See text description and table A-2.

a. Standard errors are in parentheses.

was no tendency for closeness (as measured by $O C T Y$ ) to predict fewer firms. When we extended the sample to include less isolated places, such a tendency became marked. These two results together imply that our regular sample is to the right of $D^{* *}$ in figure 2, where competition from other places exerts little effect. Less isolated places must then fall between $D^{*}$ and $D^{* *}$ in the figure.

\section{UNDERSTANDING INDUSTRY DIFFERENCES}

The marked differences in entry threshold ratios between professional and retail industries confirmed our opinion that the two groups are distinct. Our division into two groups seemed a priori to reflect real economic differences. The professional group has large fixed, possibly sunk, costs. The other industries may also, but the case is harder to prove. Our empirical finding is weak evidence that industries with large 
fixed and sunk costs have little entry. Of course, many have speculated that sunk assets are critical in the theory of barriers to entry.

There are, however, several exceptions to this rule. Automobile dealers appear to belong in the retail group, given the high frequency of entry into monopoly markets. Electrical contractors, movie theaters, and tire dealers appear (at their point estimates, at least) to belong in the infrequent-entry group. Finally, veterinarians appear to stand out, in at least some specifications, as having very little entry. The obvious reason is that movie theaters have substantial fixed and sunk costs, though they are physical, not human, capital. Thus this industry could easily be classified into the other category, thereby reinforcing the point that large fixed and sunk costs restrict entry.

The results for tire dealers and electrical contractors frankly baffled us. Why should tire dealers have less entry than car dealers? Why should electrical contractors be so different from heating, cooling, and plumbing contractors? Perhaps there is a ready source of entrants into heating, cooling, and plumbing contracting from the other two contracting categories. But this explanation still leaves quite a few electrical contracting monopolies unexplained. Similarly, it is not obvious why auto dealers and veterinarians stand out.

We have no quantitative information about the level of sunk costs in these industries. We are not particularly concerned, however, that we are unable to provide a complete explanation of interindustry variations in the ETR. The primary conclusion must be, after all, that industries do differ. By construction, the ETR accounts for scale economy explanations of monopoly. Thus interindustry variation in the ETR necessarily means that there is interindustry variation in the impact of strategic forces on entry.

\section{A FAILING EXPLANATION}

Since the variations in ETRs among industries appear to be driven by fixed costs, we searched for explanations from governmental forces as well as forces inside the local market. Effective governmental licensure or restrictions on entry should have appeared in our results as an increase in the fixed costs of both the first and the second firm into the market: state government licensure regulations typically do not block the entry of the second firm into a particular local market any more than the first. However, there might be some subtle effects of governmental limitations 
on mobility that account for lack of entry into the sample monopoly markets.

The impact of government regulation on entry into the professions and on professional mobility has been analyzed in the substantial literature on occupational licensure. B. Peter Pashigian has examined the effects of licensure on a great many occupations. Table 8 includes information from his study about the extent of licensure. ${ }^{41}$ It is certainly hard to conclude on this basis that variations in licensure among occupations explain the differences in ETRs across industries in our sample. Veterinarians, for example, pass B. Peter Pashigian's more stringent standard, as do most of the occupations we considered, but they are not among the occupations that have particularly limited reciprocity among the states.

Pashigian also provides some evidence about the inter- and intrastate mobility behavior of the occupations. ${ }^{42}$ Those of our industries that Pashigian covers are ordered from most mobile to least mobile as follows:

\begin{tabular}{ll}
\multicolumn{1}{c}{ Intrastate } & \multicolumn{1}{c}{ Interstate } \\
Electricians & Electricians \\
Plumbers & Physicians \\
Hairdressers & Plumbers \\
Barbers & Opticians \\
Dentists & Dentists \\
Opticians & Hairdressers \\
Pharmacists & Barbers \\
Optometrists & Optometrists \\
Physicians & Pharmacists
\end{tabular}

This would seem to suggest that pharmacists and optometrists have the largest barriers to entry, since they stand out as the least mobile within or among states. Electricians are hardly the candidates for firms encountering high entry barriers; they are the most mobile on both accounts. We conclude that we are unlikely to find an explanation of the apparent variation in barriers to entry from mobility barriers.

It seems, then, that the government-based theory of the variation

41. B. Peter Pashigian, "Has Occupational Licensing Reduced Geographical Mobility and Raised Earnings?' in Simon Rottenberg, ed., Occupational Licensure and Regulation (Washington, D.C.: American Enterprise Institute, 1980), pp. 299-333.

42. The relevant evidence is in his table 8 . Pashigian estimates equations in which the dependent variables are the logs of migration rates, both intra- and interstate. We ordered professions by their coefficients. 
Timothy F. Bresnahan and Peter C. Reiss

Table 8. Industry Profiles and Regulation

\begin{tabular}{lrrrc}
\hline \multicolumn{1}{c}{ Industry } & $\begin{array}{c}\text { Number } \\
\text { of firms }\end{array}$ & $\begin{array}{c}\text { People } \\
\text { per firm }\end{array}$ & $\begin{array}{c}\text { Regulatory } \\
\text { Standard }^{\mathrm{a}}\end{array}$ & $\begin{array}{c}\text { Regulatory } \\
\text { reciprocity?d }\end{array}$ \\
\hline Doctors & 58,305 & 4,142 & $\mathrm{I}$ & $\mathrm{Y}$ \\
Dentists & 147,632 & 1,636 & $\mathrm{I}$ & $\mathrm{N}$ \\
Pharmacists & 55,473 & 4,353 & $\mathrm{I}$ & $\mathrm{Y}$ \\
Veterinarians & 42,053 & 5,742 & $\mathrm{I}$ & $\mathrm{Y}$ \\
Optometrists & 30,465 & 7,927 & $\mathrm{I}$ & $\mathrm{Y}$ \\
Opticians & 15,699 & 15,382 & $\mathrm{II}$ & $\mathrm{Y}$ \\
Auto dealers & 27,315 & 8,841 & n.a. & n.a. \\
Tire dealers & & & & \\
$\quad$ Retail & 43,088 & 5,605 & n.a. & n.a. \\
$\quad$ Used & 2,225 & 108,534 & n.a. & n.a. \\
Theaters & 11,919 & 20,261 & n.a. & n.a. \\
Contractors & & & & \\
$\quad$ Cooling & 46,563 & 5,186 & n.a. & n.a. \\
Plumbing & 51,704 & 4,671 & II & N \\
Heating & 43,668 & 5,530 & n.a. & n.a. \\
$\quad$ Electrical & 52,239 & 4,623 & II & N \\
Barbers & 65,801 & 3,670 & I & N \\
Beauticians & 203,652 & 1,186 & I & N \\
\hline
\end{tabular}

Sources: Number in each profession is from American Business Lists, Inc. People per firm is computed using U.S. population data from Bureau of the Census, Statistical Abstract of the United States, 1987 (U.S. Department of Commerce, 1987), p. 8, table 2. Regulatory standards and regulatory reciprocity are from B. Peter Pashigian, "Has Occupational Licensing Reduced Geographical Mobility and Raised Earnings?" in Simon Rottenberg, ed., Occupational Licensure and Regulation (Washington, D.C.: American Enterprise Institute, 1980), pp. 299-333.

n.a. Not available.

a. Number as of June 1987.

b. U.S. population estimate for 1986 divided by number of firms.

c. Standard I is a more restrictive definition of regulation than standard II. See Pashigian, "Has Occupational Licensing Reduced Geographical Mobility?" table 2.

d. $\mathrm{N}$ means restrictions on reciprocity; $\mathrm{Y}$ means few restrictions on reciprocity. See Pashigian, table 2.

e. In general practice.

among industries is weak. Though government regulations affect mobility, they do not seem to create disproportionately more local monopolies.

\section{Conclusion}

The industries in our sample showed important differences in entry threshold ratios and therefore in their tendency to monopoly. Some, primarily the retail ones in our sample, appear to have little tendency to monopoly. Others, such as the health professions, have higher ETRs and tend more toward monopoly. The degree to which costs are sunk provides a potential explanation of much of these differences, on the plausible theory that professionals have greater sunk costs. 
Some but not all of the tendency toward concentrated industry structure is explained by economies of scale. As an empirical matter, the remaining variation in ETRs cannot easily be explained by governmental intervention, nor is it a result of flawed market definition. Instead, the explanation must lie in differences in the competitiveness of duopoly, in the effectiveness of entry barriers, or in the relative efficiencies of the first and second firms into markets.

Since our sample consisted of local markets, it is hard to argue that systematic differences in efficiency between the first and second firm are an explanation for our results. The other two explanations, variations in entry barriers across concentrated industries or in competitive conduct after entry, are of considerable importance in a broader context than the local markets we studied. We do not believe that these markets "stand in" for highly concentrated industries in the sectors of the economy where competition is national or global. In recent years, however, antitrust policy debates have been heavily influenced by the view that most industries have very free entry. Our results show that that view is incorrect as an empirical matter; industries vary dramatically in their entry conditions. Thus continued investigation of the ease of entry and the competitive effects of entry is an important research area.

\section{Appendix Tables}

Table A-1. Number of Professional Firms, by Size of Town

\begin{tabular}{|c|c|c|c|c|c|c|c|c|c|c|c|}
\hline \multirow[b]{2}{*}{$\begin{array}{l}\text { Number } \\
\text { of firms }\end{array}$} & \multicolumn{10}{|c|}{ Town population } & \multirow[b]{2}{*}{ Total } \\
\hline & $\begin{array}{c}\text { Less } \\
\text { than } \\
250\end{array}$ & $\begin{array}{c}250- \\
500\end{array}$ & $\begin{array}{l}500- \\
1,000\end{array}$ & $\begin{array}{c}1,000- \\
1,500\end{array}$ & $\begin{array}{c}1,500- \\
2,000\end{array}$ & $\begin{array}{c}2,000- \\
2,500\end{array}$ & $\begin{array}{c}2,500- \\
3,000\end{array}$ & $\begin{array}{c}3,000- \\
3,500\end{array}$ & $\begin{array}{c}3,500- \\
5,000\end{array}$ & $\begin{array}{c}\text { More } \\
\text { than } \\
5,000\end{array}$ & \\
\hline \multicolumn{12}{|l|}{ Dentists } \\
\hline 0 & 3 & 7 & 14 & 5 & 1 & 0 & 1 & 1 & 0 & 0 & 32 \\
\hline 1 & 0 & 2 & 17 & 23 & 12 & 6 & 4 & 2 & 1 & 0 & 67 \\
\hline 2 or more & 0 & 0 & 2 & 6 & 6 & 9 & 4 & 11 & 22 & 43 & 103 \\
\hline \multicolumn{12}{|l|}{ Plumbers } \\
\hline 0 & 2 & 9 & 25 & 18 & 8 & 1 & 3 & 3 & 1 & 1 & 71 \\
\hline 1 & 1 & 0 & 7 & 13 & 6 & 9 & 2 & 2 & 4 & 3 & 47 \\
\hline 2 or more & 0 & 0 & 1 & 3 & 5 & 5 & 4 & 9 & 18 & 39 & 84 \\
\hline \multicolumn{12}{|c|}{ Heating contractors } \\
\hline 0 & 3 & 9 & 28 & 25 & 14 & 11 & 4 & 5 & 11 & 7 & 117 \\
\hline 1 & 0 & 0 & 4 & 9 & 3 & 2 & 3 & 5 & 7 & 7 & 40 \\
\hline 2 or more & 0 & 0 & 1 & 0 & 2 & 2 & 2 & 4 & 5 & 29 & 45 \\
\hline
\end{tabular}


Table A-1. (continued)

\begin{tabular}{|c|c|c|c|c|c|c|c|c|c|c|c|}
\hline \multirow[b]{2}{*}{$\begin{array}{l}\text { Number } \\
\text { of firms }\end{array}$} & \multicolumn{10}{|c|}{ Town population } & \multirow[b]{2}{*}{ Total } \\
\hline & $\begin{array}{c}\text { Less } \\
\text { than } \\
250\end{array}$ & $\begin{array}{c}250- \\
500\end{array}$ & $\begin{array}{l}500- \\
1,000\end{array}$ & $\begin{array}{c}1,000- \\
1,500\end{array}$ & $\begin{array}{c}1,500- \\
2,000\end{array}$ & $\begin{array}{c}2,000- \\
2,500\end{array}$ & $\begin{array}{c}2,500- \\
3,000\end{array}$ & $\begin{array}{c}3,000- \\
3,500\end{array}$ & $\begin{array}{c}3,500- \\
5,000\end{array}$ & $\begin{array}{l}\text { More } \\
\text { than } \\
5,000\end{array}$ & \\
\hline \multicolumn{12}{|c|}{ Cooling contractors } \\
\hline 0 & 3 & 9 & 30 & 33 & 15 & 13 & 7 & 13 & 11 & 19 & 153 \\
\hline 1 & 0 & 0 & 3 & 1 & 3 & 2 & 1 & 0 & 6 & 14 & 30 \\
\hline 2 or more & 0 & 0 & 0 & 0 & 1 & 0 & 1 & 1 & 6 & 10 & 19 \\
\hline \multicolumn{12}{|c|}{ Electrical contractors } \\
\hline 0 & 3 & 8 & 19 & 15 & 7 & 3 & 1 & 2 & 2 & 0 & 60 \\
\hline 1 & 0 & 1 & 9 & 13 & 7 & 7 & 2 & 3 & 8 & 4 & 54 \\
\hline 2 or more & 0 & 0 & 5 & 6 & 5 & 5 & 6 & 9 & 13 & 39 & 88 \\
\hline \multicolumn{12}{|c|}{ Beauty shops } \\
\hline 0 & 1 & 3 & 5 & 0 & 1 & 0 & 0 & 0 & 0 & 0 & 10 \\
\hline 1 & 2 & 4 & 8 & 9 & 1 & 1 & 0 & 0 & 1 & 0 & 26 \\
\hline 2 or more & 0 & 2 & 20 & 25 & 17 & 14 & 9 & 14 & 22 & 43 & 166 \\
\hline \multicolumn{12}{|c|}{ Barber shops } \\
\hline 0 & 3 & 8 & 28 & 20 & 12 & 6 & 4 & 5 & 5 & 4 & 95 \\
\hline 1 & 0 & 1 & 5 & 12 & 6 & 7 & 3 & 6 & 14 & 12 & 66 \\
\hline 2 or more & 0 & 0 & 0 & 2 & 1 & 2 & 2 & 3 & 4 & 27 & 41 \\
\hline \multicolumn{12}{|c|}{ Farm equipment dealers } \\
\hline 0 & 3 & 7 & 20 & 19 & 7 & 3 & 4 & 5 & 11 & 11 & 90 \\
\hline 1 & 0 & 2 & 8 & 7 & 5 & 4 & 1 & 3 & 3 & 6 & 39 \\
\hline 2 or more & 0 & 0 & 5 & 8 & 7 & 8 & 4 & 6 & 9 & 26 & 73 \\
\hline \multicolumn{12}{|c|}{ Optometrists } \\
\hline 0 & 3 & 9 & 32 & 32 & 19 & 14 & 8 & 14 & 17 & 25 & 173 \\
\hline 1 & 0 & 0 & 1 & 2 & 0 & 1 & 1 & 0 & 5 & 9 & 19 \\
\hline 2 or more & 0 & 0 & 0 & 0 & 0 & 0 & 0 & 0 & 1 & 9 & 10 \\
\hline \multicolumn{12}{|l|}{ Drugstores } \\
\hline 0 & 3 & 7 & 15 & 1 & 1 & 0 & 0 & 1 & 0 & 0 & 28 \\
\hline 1 & 0 & 2 & 14 & 26 & 9 & 4 & 3 & 1 & 3 & 0 & 62 \\
\hline 2 or more & 0 & 0 & 4 & 7 & 9 & 11 & 6 & 12 & 20 & 43 & 112 \\
\hline \multicolumn{12}{|l|}{ Physicians } \\
\hline 0 & 3 & 8 & 12 & 9 & 4 & 0 & 1 & 0 & 0 & 0 & 37 \\
\hline 1 & 0 & 1 & 17 & 13 & 7 & 7 & 3 & 7 & 3 & 3 & 61 \\
\hline 2 or more & 0 & 0 & 4 & 12 & 8 & 8 & 5 & 7 & 20 & 40 & 104 \\
\hline \multicolumn{12}{|l|}{ Opticians } \\
\hline 0 & 2 & 8 & 26 & 16 & 7 & 2 & 3 & 2 & 2 & 0 & 68 \\
\hline 1 & 1 & 1 & 7 & 17 & 11 & 12 & 4 & 9 & 12 & 11 & 85 \\
\hline 2 or more & 0 & 0 & 0 & 1 & 1 & 1 & 2 & 3 & 9 & 32 & 49 \\
\hline \multicolumn{12}{|c|}{ Tire dealers } \\
\hline 0 & 2 & 8 & 15 & 14 & 3 & 1 & 0 & 1 & 0 & 1 & 45 \\
\hline 1 & 1 & 1 & 13 & 11 & 2 & 3 & 2 & 3 & 3 & 0 & 39 \\
\hline 2 or more & 0 & 0 & 5 & 9 & 14 & 11 & 7 & 10 & 20 & 42 & 118 \\
\hline \multicolumn{12}{|c|}{ Veterinarians } \\
\hline 0 & 2 & 9 & 20 & 10 & 3 & 2 & 1 & 3 & 2 & 1 & 53 \\
\hline 1 & 1 & 0 & 12 & 19 & 14 & 7 & 5 & 4 & 8 & 10 & 80 \\
\hline 2 or more & 0 & 0 & 1 & 5 & 2 & 6 & 3 & 7 & 13 & 32 & 69 \\
\hline
\end{tabular}

Source: Authors' calculations with data from American Business Lists. 
Table A-2. Sample Statistics

\begin{tabular}{|c|c|c|c|c|}
\hline Variable & Mean & $\begin{array}{l}\text { Standard } \\
\text { deviation }\end{array}$ & $\begin{array}{l}\text { Mini- } \\
\text { mum }\end{array}$ & $\begin{array}{l}\text { Maxi- } \\
\text { mum }\end{array}$ \\
\hline Dentists (TDENTIST) & 2.6 & 3.1 & 0 & 17 \\
\hline Plumbers $(T P L U M B)$ & 2.2 & 3.3 & 0 & 25 \\
\hline Heating contractors (THEAT) & 1.0 & 1.7 & 0 & 11 \\
\hline Cooling contractors $(T C O O L)$ & 0.4 & 0.8 & 0 & 4 \\
\hline Electricians (TELECT) & 2.2 & 2.9 & 0 & 18 \\
\hline Beauty shops (TBEAUTY) & 6.0 & 5.8 & 0 & 32 \\
\hline Barber shops (TBARBER) & 0.9 & 1.2 & 0 & 5 \\
\hline Farm equipment dealers (TFARM) & 1.5 & 2.0 & 0 & 15 \\
\hline Optometrists (TOPTOM) & 0.2 & 0.7 & 0 & 4 \\
\hline Drugstores (TDRUG) & 1.9 & 1.6 & 0 & 11 \\
\hline Physicians (TDOCTOR) & 3.4 & 5.4 & 0 & 45 \\
\hline Opticians (TOPTIC) & 1.0 & 1.0 & 0 & 5 \\
\hline Tire dealers (TTIRE) & 2.6 & 2.6 & 0 & 13 \\
\hline Veterinarians (TVET) & 1.3 & 1.2 & 0 & 8 \\
\hline Theaters (THEATERS) & 0.9 & 1.0 & 0 & 4 \\
\hline Auto dealers (TCARD) & 2.0 & 1.6 & 0 & 11 \\
\hline \multicolumn{5}{|l|}{ County Data } \\
\hline Land area (sq. miles) (LAND) & $2,806.9$ & $3,008.9$ & 407 & 18,155 \\
\hline County population (POP80) & $17,423.0$ & $106,553.0$ & 513 & $1,509,052$ \\
\hline Female population (FEMALE80) & $8,774.1$ & $54,306.5$ & 247 & 769,261 \\
\hline \multicolumn{5}{|l|}{ Moved within state-different county } \\
\hline (CMOVE80) & $1,099.9$ & $2,771.8$ & 77 & 36,728 \\
\hline Moved out of state (SMOVE80) & $3,519.0$ & $26,999.6$ & 39 & 382,163 \\
\hline Population 65 and older $(O L D 80)$ & $2,013.3$ & $12,311.4$ & 64 & 174,732 \\
\hline Population 18 and older (NOTEEN80) & $12,173.6$ & $76,544.1$ & 377 & $1,085,178$ \\
\hline Median age (MEDAGE80) & 31.4 & 4.7 & 21 & 49 \\
\hline Total families (FAMILIES) & $4,568.3$ & $28,055.7$ & 148 & 397,610 \\
\hline \multicolumn{5}{|l|}{ Households with female head } \\
\hline$(A F A M F E M)$ & 481.1 & $3,407.0$ & 7 & 48,266 \\
\hline Number births 1980 (BIRTHS) & 332.3 & $1,897.1$ & 6 & 26,761 \\
\hline Number died 1980 (DEATHS) & 145.5 & 830.2 & 3 & 11,769 \\
\hline Housing units (HOUSES) & $7,318.7$ & $43,114.8$ & 233 & 610,772 \\
\hline Worked outside county 1980 (OCTY) & 318.9 & 688.0 & 2 & 8,387 \\
\hline \multicolumn{5}{|l|}{ Population 25 or older } \\
\hline with college $(C O L L)$ & $1,498.0$ & $11,345.5$ & 27 & 161,232 \\
\hline Households 1980 (HHOLD80) & $6,139.8$ & $38,454.5$ & 210 & 545,503 \\
\hline
\end{tabular}


Table A-2. (continued)

\begin{tabular}{|c|c|c|c|c|}
\hline Variable & Mean & $\begin{array}{l}\text { Standard } \\
\text { deviation }\end{array}$ & $\begin{array}{l}\text { Mini- } \\
\text { mum }\end{array}$ & $\begin{array}{l}\text { Maxi- } \\
\text { mum }\end{array}$ \\
\hline \multicolumn{5}{|l|}{ Median household income (\$) } \\
\hline$(M E D H I N C)$ & $13,562.4$ & $2,899.7$ & 7,358 & 26,060 \\
\hline Per capita income (\$) $(P I N C)$ & $5,908.5$ & $1,132.4$ & 3,159 & 10,504 \\
\hline Total families 1980 (TOTFAM80) & $4,614.2$ & $28,231.6$ & 153 & 400,084 \\
\hline \multicolumn{5}{|l|}{ Paid employment of retail trade } \\
\hline$($ RETEMP) & 965.1 & $6,504.9$ & 11 & 91,853 \\
\hline $\begin{array}{l}\text { Annual payroll of retail trade } \\
\text { (\$ millions) }(\text { RETPAY) }\end{array}$ & $5,943.7$ & $42,108.1$ & 33 & 594,696 \\
\hline \multicolumn{5}{|l|}{ Retail sales 1980 ( $\$$ thousands) } \\
\hline$($ RETSAL80) & $52,887.0$ & $341,073.9$ & 341 & $4,835,775$ \\
\hline Percent of land in farms (FFARM) & 67.05 & 35.09 & 0 & 127.2 \\
\hline \multicolumn{5}{|l|}{ Farms with sales of $\$ 2,500$ or more } \\
\hline \multicolumn{4}{|l|}{ Farms with sales of $\$ 40,000$ or more } & 775 \\
\hline Per farm land value $(\$)(F A R M V A L)$ & $602,994.4$ & $504,454.7$ & 42,500 & $3,889,666$ \\
\hline Per acre farm value $(\$)(F L A N D V A L)$ & 294.6 & 226.3 & 73 & 1,635 \\
\hline Hundreds of animals (PIGS) & 46.4 & 93.9 & 0.00 & 621.780 \\
\hline Hundreds of animals (COWS) & 504.8 & 412.3 & 0.00 & $2,752.030$ \\
\hline Hundreds of animals (SHEEP) & 143.7 & 269.5 & 0.00 & $1,857.900$ \\
\hline Hundreds of animals (HORSES) & 9.54 & 11.2 & 0.00 & 86.580 \\
\hline $\log$ (heating degree days) ${ }^{\mathrm{a}}(\ln H E A T)$ & 8.59 & 0.472 & 6.83 & 9.200 \\
\hline $\log \left(\right.$ cooling degrees days) ${ }^{a}(\ln C O O L)$ & 6.72 & 0.732 & 4.67 & 8.353 \\
\hline $\begin{array}{l}\text { Payroll }(\$ / 1,000) \text { employees } \\
\quad(\text { RETWAG) }\end{array}$ & 5.37 & 1.701 & 2.53 & 8.708 \\
\hline \multicolumn{5}{|l|}{ Town Data } \\
\hline 1980 population of town $1($ TPOP $)$ & $3,744.2$ & $5,350.7$ & 124 & 45,086 \\
\hline Nearby population $(O P O P)$ & 410.7 & 741.7 & 11.0 & $5,844.9$ \\
\hline $\begin{array}{l}\text { Negative part of town } 1 \text { population } \\
\text { growth }(N G R W)\end{array}$ & -57.0 & 145 & $-1,345$ & 0 \\
\hline $\begin{array}{l}\text { Positive part of town } 1 \text { population grow } \\
(P G R W)\end{array}$ & 490.0 & $1,051.0$ & 0 & 7,229 \\
\hline
\end{tabular}

Sources: Industry data from ABL; county and town data from U.S. Bureau of the Census, County and City Data Book, 1983 (U.S. Department of Commerce), tables B and C.

a. Heating degree days is the total over days of the year of the number of degrees one would need to increase temperature up to a standard; cooling degree days is similar. We classify heating degree days and cooling degree days as county data even though these are actually defined for cities. We associate with each sample point the value of these variables for the nearest city of population 25,000 or greater. 


\section{Comments and Discussion}

Robert Willig: This paper is enormously rich, stimulating, and creative; I believe it will have a significant effect on how we think about industries. The major contribution of the paper is the idea of threshold market sizes, the entry threshold ratio. At first, ETRs seem a little alien, but estimating them will very soon become a cottage industry for empirical researchers.

My major criticism of the paper is its conclusion. The authors say that where the entry threshold ratio is larger than two, there are entry problems. And where the ETR is just two, so that the firms have presumably divided the market fifty-fifty, price is unchanged from monopoly to duopoly, and the market is twice the size of that necessary to support a single firm. In such a case there is no entry barrier at all, and there is a "good market."

I am baffled at this conclusion. The model has a fixed cost and a constant marginal cost thereafter, so there are globally increasing returns to scale or natural-monopoly cost conditions. The authors deliberately make this assumption, and they support it by arguing that these are small markets or that fixed costs are going to be important in this kind of market. I accept that.

Of course, where there is natural monopoly and a homogeneous product, cost efficiency calls for one firm, not many. But having only one firm may mean that it might very well price in an ugly way. And we all know that there are trade-offs in our familiar oligopoly models between the cost inefficiencies of several firms and the beneficial effects on pricing.

Roger Koenker and Martin Perry develop the welfare measures for lots of familiar oligopoly models, using familiar functional forms. ${ }^{1}$ Their

1. Roger W. Koenker and Martin K. Perry, "Product Differentiation, Monopolistic Competition, and Public Policy," Bell Journal of Economics, vol. 12 (Spring 1981), pp. 217-31. 
numbers uniformly show a tendency toward free entry, leading to too many firms from the point of view of overall social welfare. In these kinds of models, free entry means that entry proceeds until the next firm, if it were to join, could no longer cover its costs in the postentry equilibrium. It is not hit-and-run entry. It is just that the entrants join in the current mode of behavior and do not upset the applecart, except that they increase $N$ by one, so entry is conditional on the number of firms in postentry equilibrium.

It is that kind of world that Koenker and Perry find: too many firms in free entry. But that is the very idea that underlies this paper. If the ETR is four, for example, then it takes a market four times as big as the monopoly-threshold market to support a second firm, using the conventional idea of free entry. Thus if the authors had a market with an ETR of four, they would decry the absence of a second firm. If the town were only three times as big as the threshold-monopoly town, they would say it has an unfortunate monopoly, whereas in a normal oligopoly model an ETR of four would still encourage free entry.

So, I am baffled about this paper's intuition, even from the very standard framework of oligopoly theory, from the point of view of the normative side.

I would like to discuss the kinds of ETRs one would expect in different kinds of industries, drawing on some other conventional models, or models that I find conventional, and to begin to enrich our intuition about what is a good or a bad ETR and under what conditions one would expect to see it be greater than two, equal to two, or whatever.

If the world is perfectly competitive, one must try to find a competitive structure for these little towns. There may well be only one auto dealer in town. It is a very small town, but people can drive 150 miles roundtrip to other towns where there may be a dealer offering the same brand or a different brand. A drive of 200 miles roundtrip may even put them in range of a town with two auto dealers. The pricing behavior of the auto dealer in the small town is obviously constrained by the possibility that people will drive 200 miles to save a fat monopoly margin on a $\$ 10,000$ car. That is a reasonable trip to take.

Different markets, of course, will have different degrees of cost for out-of-town consumers. Different products will correspond to different shopping costs, relative to how much money consumers can expect to save. In some markets, a product will just be too expensive. Such a 
situation will constrain the monopoly. In other markets it may be quite constraining. So, other towns are relevant, at least for lots of these goods. And, considering that the monopoly level of profit in one-dealer towns may be small relative to the duopoly level of profit, which would mean that the ETR is predictably two with no change, or very little, between monopoly and duopoly profit, the town that is twice as large will have twice as many firms. An ETR of two is thus consistent with a very competitive situation.

For cars, then, one would expect a low ETR. People are willing to drive to get better prices. Veterinarians, however, may be a different story. Can a veterinarian located 150 miles away be induced to attend a sick cow? Probably not. Or the case may prove very expensive. Can the cow be delivered to the vet? It may be difficult to move a sick cow. The monopoly level is thus probably high in towns with one veterinarian relative to those with a duopoly because there is no threat from adjacent markets, suggesting a big ETR. And that is what the authors have found.

Again, when my electricity goes down, it is an emergency. I will not go looking for an electrician, nor am I willing to call a town one-hundred miles away to get one. I am bound to my local electrician for repairing electrical failures. This suggests a high ETR because monopoly and duopoly locally would be quite different. But contrast this situation with an airconditioning problem. A person can live with an extra ten degrees of heat in a house or an office, so he can wait for some airconditioning technician to come in from another town when the technician has free time. This would lead to a much smaller ETR.

What if instead of a perfectly competitive situation, we have a perfectly contestable situation? An average cost $(A C)$ curve (figure 1) essentially bottoms out. Call it MES. It does not turn up because we want to preserve the idea of some kind of global nondecreasing returns to scale. The level of the market at which monopoly first becomes able to cover its costs corresponds to this demand curve. As one expands these demand curves radially, which is what this paper does, at the first radial expansion the market will support two firms, given that the market remains contestable. The answer is a double $M E S$. That is the first level of market expansion, at which one can actually see duopoly. $S M$ corresponds to this demand curve, and it is quite general for this shape of average cost curve. It will make the ETR be significantly greater than two because two $M E S$ is twice as big as one MES. By the Chamberlinian argument, one $M E S$ is well larger than the tangency point where monopoly can first cover cost. 
Figure 1. Contestability and Market Entry

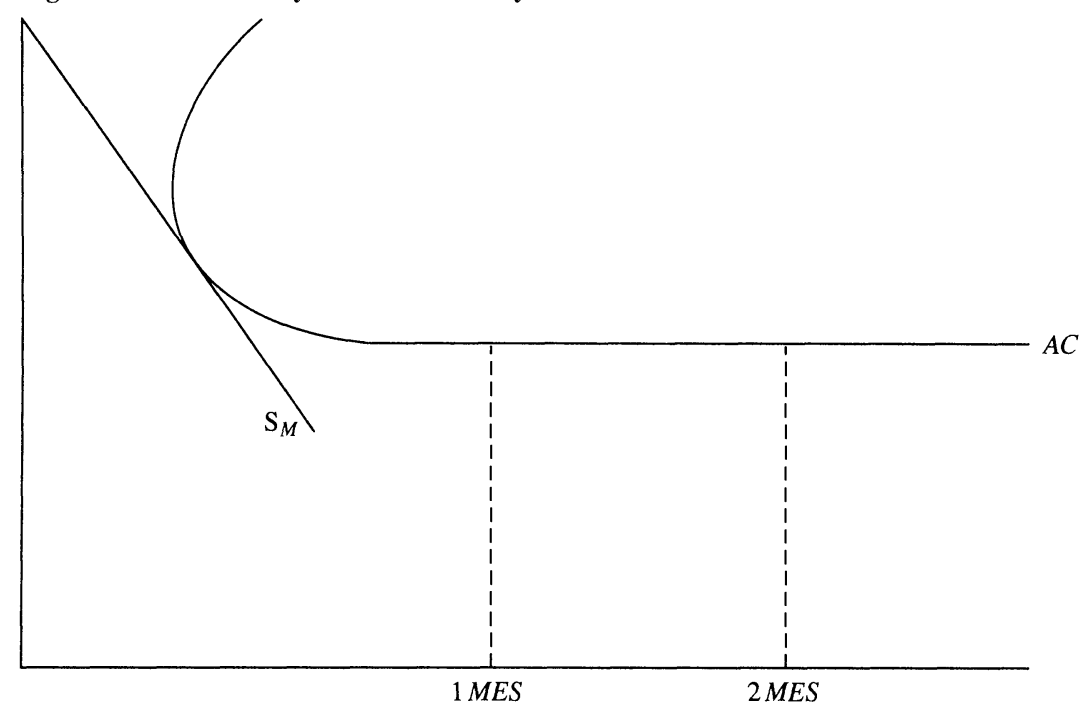

As soon as demand is big enough to allow the firm to cover costs on the flat portion of the average cost $(A C)$ curve, then in this contestable world the price will be down at the flat and the firm will be operating along that portion. So, the ETR is significantly greater than two. How much greater depends upon the shape of the downward slope and part of the average cost curve. There is thus a high ETR, perfectly free entry-in the contestable sense, not the oligopoly sense-and all along the way pushing the price up.

What this shows is that a model can have large ETRs and no entry barriers at all: "ultra free entry" as a friend once said.

Equations from the entry model of Richard Gilbert and Richard Harris provide a way to accommodate a situation such as the following. ${ }^{2}$ If small towns are growing or their economic activity is growing, in an early stage of the growth they may have no firms in a market. Later they may have one and later yet, two. When does the monopoly firm enter? At a time determined by the size of the market but also by perfectly anticipated realization that duopoly will occur later. Given the linear framework, it is easy to do the analytics of Gilbert and Harris and get an expression for the relationship between the ETR and the ratio between

2. Richard J. Gilbert and Richard G. Harris, "Competition with Lumpy Investment," Rand Journal of Economics, vol. 15 (Summer 1984), pp. 197-212. 
monopoly-flow profit and duopoly-flow profit. There, too, if the growth rate is zero or tends to zero, the formulas collapse to the static formulas that Timothy Bresnahan and Peter Reiss show in their paper. But the more growth there is in the market, the smaller the ETR for any given ratio of monopoly profit to duopoly profit. The more growth there is, the more competitive the firms can be in duopoly and yet still create an ETR equal to two.

Finally, if one takes the Gilbert and Harris world and assumes that capacity does not increase in an uneven manner, which is the way Gilbert-Harris works, but that instead incumbent firms increase capacity in a more slow and continuous fashion, then the incumbent has an incentive to overbuild capacity or to preempt in the building of capacity in a way that will tend to discourage even efficient entrants.

Now, what does that take in this model? It takes the ability to sink volume-sensitive costs, variable costs, the marginal costs of the model. In industries where the variable costs are committed, one would expect less entry, higher ETRs, and there would be enormous significance of bad performance from large ETRs. Consider movie theaters that can add screens to show yet more movies and thereby deter the entry of new theaters under independent management. Such an action would tend to increase the ETR, and movie theaters have a large ETR as I recall.

Perhaps veterinarians can hire helpers without bumping into the same constraints that physicians bump into and can expand capacity to serve in a more flexible way, steering clear of the restraints of the law. This might lead them to have a very high ETR.

My main point is to praise this paper because the empirical picture that ETRs point to stimulates imagining such situations. Moreover, if other information about industries were available-if there were plenary data or even less formal information, such as what a minimum efficient scale is or how far people will go to shop or how firms actually behave as an industry grows in a town-one might see whether incumbents make small capacity additions. If such information were added to the ETRs, one could really begin to separate out the stories, I think, in a very powerful way.

George J. Stigler: In an age when so many problems of industrial organization are solved with a hypothetical matrix of payoffs, it is pleasant to find Timothy Bresnahan and Peter Reiss employing an empirical analysis of the effects of entry on monopoly. 
However, their theoretical model seems so close to the characteristics they find in the retailing of automobiles in rural markets that it is difficult at times to separate the theory from the facts. ${ }^{1}$ For example, they postulate constant marginal costs, so the minimum size of firms is set only by fixed costs. This is conceivably an approximation of the costs of automobile retailing. But at other times they assume empirical relationships that do not seem appealing in automobile retailing-for example that the fixed or variable costs, or both, of a second firm are higher than those of the first firm in the market.

Their model, then, predicts that once a market becomes large enough to support one firm, there will usually be an entrant. When the market becomes large enough to support a second firm-a size more than twice that of the monopoly market because of the assumption of higher costs for the second firm - the second firm will also usually enter. Apparently they assume that the monopoly firm does not price its services to discourage entry, although they do not test this possibility. The effect of a third firm is not examined.

To implement the model they must identify monopolists and therefore the markets for the retailing of automobiles. To find monopolies, they choose rural areas, and I shall devote my attention almost exclusively to this fundamental step.

Bresnahan and Reiss construct their markets very much as Johann Heinrich von Thunen constructed his isolated state. ${ }^{2}$ The county is the unit, and the market consists of its largest town (sometimes modified for factors such as people living within 10 miles of the town) with certain qualifications, such as that no very large city is within 125 miles of the town. Their 149 towns have a mean population of 1,885 . The market towns in effect answer the question: How far would Bresnahan and Reiss drive to buy a car and have it serviced? How fortunate that they did not collaborate with a colleague of mine who used to take a bus from Chicago to Detroit to buy his automobiles more cheaply.

I doubt very much that these markets approach economic markets. We could test them crudely by seeing how many cars are registered in the town the authors define as a market. I predict that the number substantially exceeds the accumulated sales of the dealers in the town. Indeed, they find no dealers in 34 towns with a mean population of 817 .

1. These comments are directed toward an earlier version of the authors' paper.

2. Johann Heinrich von Thuren (1783-1850), The Isolated State, translated by Carla M. Wartenberg (Pergamon Press, 1966). 
Do these people walk? Again, I predict that the registrations would reveal substantial numbers of automobile makes not represented by dealers in their market. In addition, automobile repairs account for onefifth of the receipts of automobile dealers and a considerably higher share of the purchase and repair expenditures of drivers and of the valueadded of dealers. I suspect that repair services have different markets in significant respects from those of car retailing. The independent repair shops muddy the count of firms.

The authors reinforce their concept of market in the finding that the variable representing population adjacent to the town and the share of town population commuting to work outside the county do not enter significantly into statistical analyses using their market concept. The easy alternative interpretation is that their concept is so defective that minor amendments cannot save it. A fundamental test of their markets could be made either by a survey of auto owners or by a comparison of retail price levels and movements of automobiles across their markets and neighboring areas.

Thus the ambiguity of their market concept introduces a fundamental ambiguity in their results. The demand curves for their markets are probably highly elastic, and their model should yield primarily competitive results in the rural retail automobile market.

A problem is raised by the study of cross-sectional data on market entry. The authors observe no entry and must employ the differences between two-dealer towns in 1980 (after corrections for per capita income and demographic variables) to estimate what change in market size attracted a second dealer. Their dealer count pertains only to 1982 , so they have no knowledge of entry, and in particular must assume that all entrants date from long enough ago to have reached long-run equilibrium. Their data source presumably would have allowed a count of dealers by market for earlier years. Hence their findings are strictly relevant only to equilibrium market structures and shed only a weak light on entry.

I accept their main conclusion that entry of a second dealer does not lead to a large increase in competition. I attribute this result to the fact that there was not much room for an increase in competition.

One can also analyze the effects of numbers of rivals on competition more directly, and in particular measure the effects on price. A wellknown example is Reuben Kessel's study of the effect of the number of consortia bidding for a new issue of state or local government bonds on 
the bidding price, reoffer price, and underwriters' spread. ${ }^{3}$ His sample was huge, so corrections should be made for size of issue, call provisions, credit rating of the issue, and so on. After correcting for such differences among issues, Kessel found a powerful effect of number on underwriters' spreads, for example. One attained full competition with at most a dozen bidders, and the excess of the underwriters' spread per bond with fewer numbers was, for general obligation bonds, $\$ 5.09$ with one bidder, $\$ 2.50$ with two bidders, $\$ 2.33$ with three bidders, and finally, $\$ 0.72$ with six bidders. Thus only a single additional rival was necessary to halve the monopoly premium in the spread. This kind of analysis is possible for a variety of markets. The advantage of such an approach compared with that of Bresnahan and Reiss is that it requires many fewer assumptions, although obviously it faces the same problem of market determination.

\section{Discussion}

In response to Robert Willig's and George Stigler's comments, Peter Reiss claimed that the entry threshold ratio was not intended to have normative implications but to serve as a summary statistic describing something important about the conditions of entry in a market. The ETR is a concept relevant only for well-defined and distinct markets and is intended to focus attention on the distinction between competition issues and market definition issues in studies of market entry. Apparent systematic differences among industries in the magnitude of the ETRs suggests, he added, that it may be possible to identify factors such as sunk costs that account for these differences.

Reiss also noted that the study provides information that could help to establish that the ETR exceeds two because the incumbent firm raises barriers to entry. This would counter Willig's proposal that the second firm does not enter until the market is at least twice that necessary to support a firm operating at the minimum efficient scale. This entry size may be much larger than the monopoly entry size, and hence result in an ETR much larger than two. If the latter hypothesis is true, Reiss pointed out, variable profits should not fall after entry. For some of the markets studied by the authors, the ratio of duopoly variable profits to

3. Reuben Kessel, "A Study of the Effects of Competition in the Tax-Exempt Bond Market," Journal of Political Economy, vol. 79 (July-August 1971), pp. 706-38. 
monopoly variable profits was estimated to be close to one, which is consistent with Willig's theory.

Richard Gilbert noted that the paper provides a measurable definition of barriers to entry that integrates both structural and behavioral characteristics of the market. To discover whether some markets tend toward monopoly would mean sorting out what factors lead to the differences in ETRs among industries. Richard Schmalensee suggested, for example, that sunk costs in the form of established reputations may be the factor that discriminates best among the industries in this study. The importance of reputations may explain why electrical contractors seem to have much higher ETRs than plumbing contractors; it may be harder to verify the quality of the electrical product or the service provided immediately after purchase. What matters is not just that the lights work but that the house not burn down, he noted.

Several participants seemed concerned that the authors' methodology may have systematically undercounted the effective number of firms performing professional services. Daniel McFadden observed that, especially in very small isolated communities, people often perform services for each other that are not in their main line of business. The service station owner may also broker cars, for example, or the local preacher may cut hair during the week. Zvi Griliches added that such people may not want to pay extra for a business phone, and hence may not have listings in the yellow pages, or may not want to be identified publicly as performing these services because they may not report the income. And John Meyer pointed out that licensing standards may often be overlooked in isolated communities. If the minister becomes a plumber on weekdays, the townspeople are unlikely to worry about his competence, even though he may not be licensed.

Edward Denison added that the study not only failed to account for such people performing services part-time but treated a group practice as a single firm, which may also lead to undercounting the number of firms in professional services. He suggested that the relevant measure of the number of "firms" should instead be the number of people performing the service. And Meyer pointed that the portability of the service in question is also relevant. People can drive into a city once a month for multipurpose shopping trips and visit their dentist, barber, or optometrist on the same trip. But plumbers, electricians, and veterinarians must perform their services on site. 
Bresnahan responded that the authors tried reclassifying multiperson firms and their results were essentially unchanged. They also used census data to check their sampling procedure for dentists and doctors and again found that their results were unchanged. Reiss defended the market definition test used by the authors against proponents of what he called the "Aunt Matilda effect." For every Aunt Matilda who is willing to drive 300 miles to get her hair cut, he asserted, there is an Uncle Charley who will not. As long as there was enough heterogeneity that the demand curves facing the firms in their sample were not perfectly elastic, then those firms had some market power, and the question posed by the authors-whether the markets tended toward monopoly-is a relevant one. 